\title{
Papel dos componentes do sistema GH-IGF-IGFBP nos mecanismos envolvidos na resposta imunológica do Diabetes Melito tipo 1
}

Tese apresentada à Faculdade de Medicina da Universidade de São Paulo para a obtenção do título de Doutor em Ciências.

Área de Concentração: Endocrinologia

Orientador: Prof. Dr. Daniel Giannella Neto

São Paulo 
À minha esposa Cristiane, a quem escolhi para a caminhada da vida.

Com você, Cris, aprendo novas coisas a cada dia e tudo se torna mais fácil...

Ao meu pai Silvano, responsável direto pela minha formação e por todas as minhas conquistas.

A você, meu pai, minha eterna gratidão... 


\section{AGRADECIMENTO ESPECIAL}

Ao meu orientador Prof. Dr. Daniel Giannella Neto, por me fazer compreender e respeitar as minhas limitações, pelo conhecimento e simplicidade demonstrados durante todos estes anos e principalmente por acreditar na minha pessoa.

A você, Daniel, meu muito obrigado! 


\section{AGRADECIMENTOS}

Este trabalho não seria possível sem a ajuda de pessoas que direta ou indiretamente contribuíram para a sua execução:

À Disciplina de Endocrinologia da Faculdade de Medicina da Universidade de São Paulo, em nome do Prof. Dr. Éder C. R. Quintão pela oportunidade de realização deste trabalho.

Ao Prof. Dr. Bernardo Léo Wajchenberg, responsável maior por minha formação endocrinológica, a quem respeito e admiro como exemplo.

À Dra. Márcia Nery, Dra. Dalva Marreiro Rocha e a Dra. Nuvarte Setian pela leitura cuidadosa e valiosas contribuições e sugestões.

À Dra. Lais Isidoro Alves pelos conhecimentos na área de Diabetes Melito tipo 1.

À Dra. Thais Della Manna que, permitindo a utilização da casuística do Instituto da Criança, tornou possível a realização deste trabalho.

Aos colegas e amigos pessoais Prof. Dr. Benjamim Cimerman e Dr. Sérgio Cimerman, que tanto contribuíram para a realização deste trabalho.

Aos colegas da Equipe Médica de Diabetes do HCFMUSP (Ana T. Santomauro, Antonio C. Lerário, Isio Schulz, Jayme Goldman, Jean J. Souza, Karla F. Melo, Karyne F. Barbosa, Maria Elizabeth R. Silva, Maria Lúcia C. Giannella e Rosa F. Santos) pelo constante aprendizado e troca de informações durante as visitas médicas. 
Ao biomédico Leonardo Sokolnik de Oliveira, co-autor deste trabalho, pela padronização e execução da metodologia de RT-PCR, imprescindível para a realização deste trabalho.

À Paula G. Strassmann e funcionários da PGS/ Medical Statistics pela análise estatística dos dados.

Aos colegas pós-graduandos do LIM-25/FMUSP pelo apoio, incentivo e amizade durante este período.

Aos funcionários do LIM-25/FMUSP pela colaboração e apoio.

Às secretárias Noriza, Cida e Rosana pela assesoria prestada durante todo este período.

Aos pacientes portadores de Diabetes Melito tipo 1 e seus familiares, que tornaram possível a realização deste trabalho.

A realização da presente investigação foi possível graças ao apoio financeiro concedido pelo CNPQ - processo $n^{\circ}$ 140770/1999-2. 


\section{ÍNDICE}

Lista de Abreviaturas

Resumo

Summary

1. INTRODUÇÃO 1

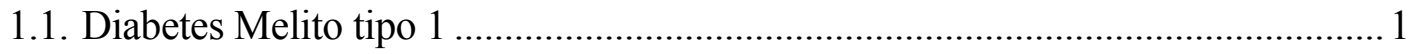

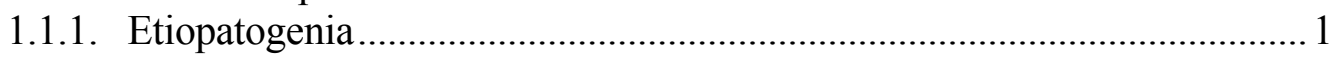

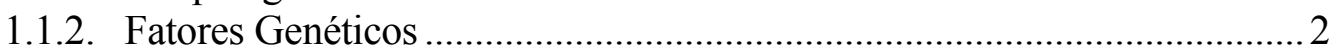

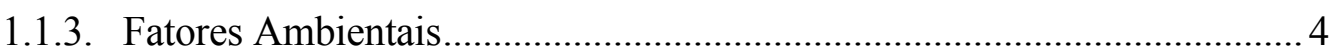

1.1.4. Auto-imunidade e os marcadores celulares............................................... 6

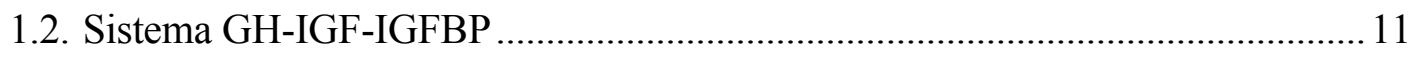

1.2.1. Fatores de Crescimento Insulina-Símile (IGFs) .................................... 11

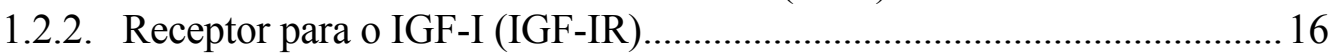

1.2.3. Proteínas de Ligação dos IGFs (IGFBPs) ................................................ 18

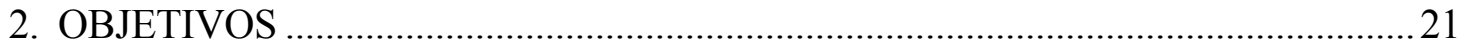

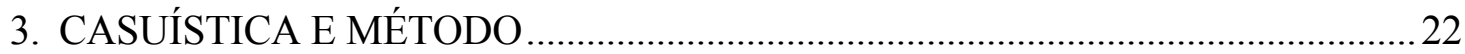

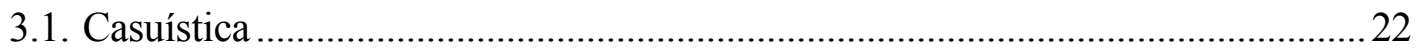

3.2. Processamento das Amostras ........................................................................... 23

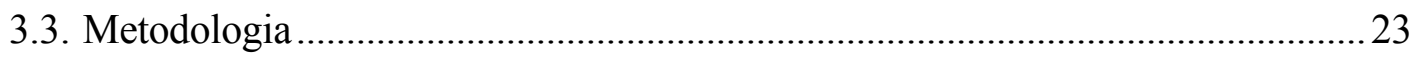

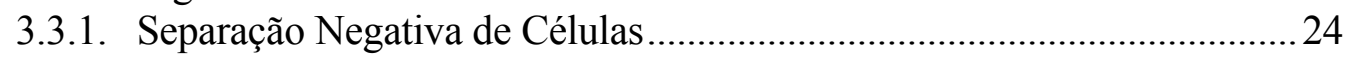

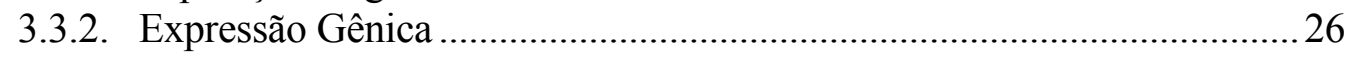

3.3.3. Determinação das concentrações plasmáticas de GH, IGF-I total,

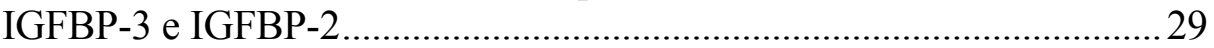

3.3.4. Determinação das concentrações plasmáticas de Frutosaminas e Peptídeo C

3.3.5. Determinação das concentrações plasmáticas de anticorpos antiilhota de Langerhans citoplasmático (ICA), anticorpos anti-tirosina fosfatase (anti-IA2) e anticorpos anti-descarboxilase do ácido

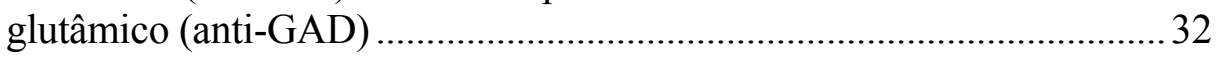

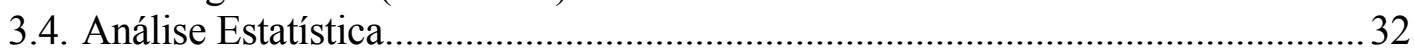

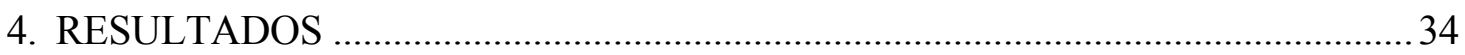

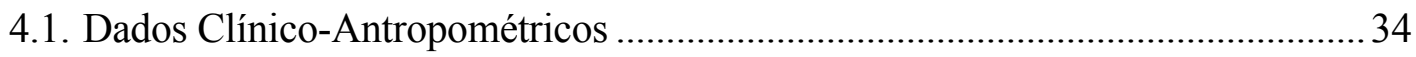

4.2. Determinação das concentrações plasmáticas de Frutosaminas e Peptídeo C .... 35

4.3. Determinação das concentrações plasmáticas de GH, IGF-I total, Z(IGF-I), IGFBP-3, Z(IGFBP-3) e IGFBP-2.

4.4. Determinação da positividade de anticorpos anti-Ilhota de Langerhans citoplasmático (ICA), anticorpos anti-tirosina fosfatase (anti-IA2) e anticorpos anti-descarboxilase do ácido glutâmico (anti-GAD) ........................... 39

4.5. Ensaio de RT-PCR para análise do mRNA do IGF-IR em Linfócitos T e B ...... 42

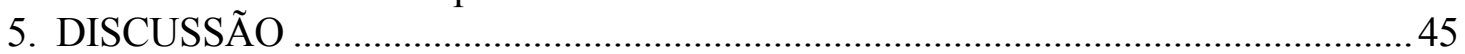

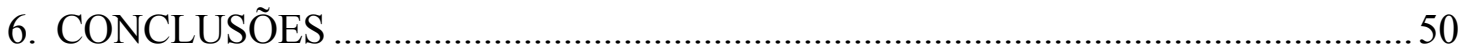

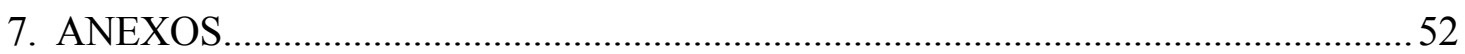

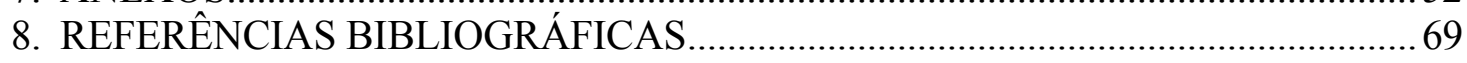




\section{LISTA DE ABREVIATURAS}

anti-GAD - Anticorpo anti-descarboxilase do ácido glutâmico

anti-IA2 - Anticorpo anti-tirosina fosfatase

APC - Célula apresentadora de antígeno

cDNA - Ácido desoxiribonucleico complementar

DEPC - Dietilpirocarbonato

DM1 - Diabetes melito tipo 1

DNA - Ácido desoxiribonucleico

dNTPs - desoxinucleotídeos trifosfatados

DTT - Ditiotreitol

EDTA - Ácido etilenodiaminotetracético

F - Sexo feminino

FRTSM - Frutosamina

GH - Hormônio de crescimento

HLA - Antígeno leucocitário humano

IAA - Anticorpo anti-insulina

ICA - Anticorpo anti-ilhota de Langerhans citoplasmático

IFN - Interferon

IGFBPs - Proteínas de ligação dos fatores de crescimento insulina-símiles

IGF-I - Fator de crescimento insulina-símile tipo I

IGF-IR - Receptor para o fator de crescimento insulina-símile tipo I

IGF-II - Fator de crescimento insulina-símile tipo II

IL - Interleucina

IRS-1 - Substrato 1 relacionado à insulina 
JNKs - Quinase Jun N-terminal

$\mathrm{KCl}$ - Cloreto de potássio

M - Sexo masculino

MAPK - Proteínas quinases associadas à mitose

$\mathrm{MgCl}_{2}$ - Cloreto de magnésio

MHC - Complexo principal de histocompatibilidade

MNC - Células mononucleares

mRNA - Ácido ribonucléico mensageiro

$\mathrm{pb}$ - Pares de bases

PBS/0,1\% BSA - Tampão fosfato salina $0,1 \%$ albumina sérica bovina

PCR - Reação em cadeia pela polimerase

PEP C - Peptídeo C

PGE2 - Prostaglandina E2

PI-3K - Fosfatidil Inositol 3-Quinase

RT-PCR - Reação em cadeia pela polimerase após transcrição reversa

TAE - Tampão Tris-Acetato-EDTA

TCR - Receptor de antígeno da célula T

Th-1 - Células T helper 1

Th-2 - Células T helper 2

TNF - Fator de necrose tumoral

Tris - Hidroximetilaminometano

U.A.D.O. - Unidades arbitrárias de densidade ótica 


\section{RESUMO}

Com o objetivo de verificar se as proteínas do sistema GH-IGF-IGFBP e o receptor do fator de crescimento insulina símile tipo I (IGF-IR) estão envolvidos na etiopatogenia do Diabetes Melito tipo 1 (DM1), foram estudados 23 pacientes prépúberes portadores de DM1 em diferentes fases do diagnóstico (Grupo A: tempo de diagnóstico $\leq 6$ meses; Grupo B: tempo de diagnóstico $>6$ meses) e 10 indivíduos pré-púberes sadios como grupo controle (Grupo C). A expressão do mRNA do IGFIR realizada através do ensaio molecular de RT-PCR nos linfócitos periféricos $\mathrm{T}$ e $\mathrm{B}$ não demonstrou diferenças estatisticamente significantes nos linfócitos $T$ quando comparados indivíduos diabéticos e controles, sugerindo que a ativação imunológica destas células seja independente da ação do IGF-IR. Observou-se uma maior expressão do mRNA do IGF-IR dos linfócitos $\mathrm{B}$ de pacientes diabéticos em relação ao grupo controle $(\mathrm{p}<0,05)$. A avaliação das proteínas do sistema GH-IGF-IGFBP não demonstrou diferença estatística significante entre os grupos. Estes achados, associados à presença de auto-anticorpos para o DM1 (ICA, anti-GAD e anti-IA2) sugerem fortemente o papel do IGF-IR na ativação dos linfócitos B envolvidos na etiopatogenia do DM1. 


\section{SUMMARY}

Aiming to verify if GH-IGF-IGFBP proteins system and insulin-like growth factor type I receptor (IGF-IR) are implicated on pathofisiology of type 1 Diabetes Mellitus (DM1), we studied 23 prepubertal patients with DM1 on different stages of diagnosis (Group A: time of diagnosis $\leq 6$ months; Group B: time of diagnosis $>6$ months) and 10 prepubertal healthy subjects as control group (Group C). The RT-PCR molecular assay for IGF-IR mRNA on peripheral T and B lymphocytes didn't show statistical differences between the groups when T cells were analyzed. We found an increase of IGF-IR mRNA expression on B cells from diabetic patients when compared to healthy subjects $(p<0,05)$. There were no differences in the GH-IGF-IGFBP proteins system levels between the groups. Our study suggest that IGF-IR in association with diabetes-related autoantibodies (ICA, anti-GAD and anti-IA2) presence could activate B cells involved on pathofisiology of DM1. 


\section{INTRODUÇÃO}

\subsection{Diabetes Melito tipo 1}

\subsubsection{Etiopatogenia}

O Diabetes Melito tipo 1 (DM1) é uma síndrome que apresenta quadro etiológico e clínico heterogêneos, sendo definida como doença crônica predominantemente auto-imune com forte determinante genético e longo período prodrômico. A fase subclínica da doença caracteriza-se pela invasão linfocitária específica das células- $\beta$ das ilhotas de Langerhans, insulite linfocitária auto-imune e produção de auto-anticorpos contra várias proteínas das ilhotas (insulina, enzima descarboxilase do ácido glutâmico, proteínas de membrana com homologia as tirosinofosfatases, gangliosídeos, carboxipeptidase $\mathrm{H}$ e outras). Este processo acarreta a destruição gradual e progressiva das células das ilhotas de Langherans (com preservação das células $\alpha$ e $\delta$ ) e posterior falência da secreção pancreática de insulina, determinando primeiramente a dependência permanente de insulina exógena para a homeostase do metabolismo glicídico e secundariamente alterações dos metabolismos proteicos e lipídicos (DOTTA \& EISENBARTH, 1997).

Etiologicamente o DM1 pode ser subdividido em tipo1A (auto-imune) e tipo1B (idiopático). Nos últimos anos, com o desenvolvimento da genética e da imunologia, houve uma maior compreensão dos mecanismos etiopatogênicos do DM1A quando comparados ao DM1B.

O DM1 pode acometer indivíduos em qualquer faixa etária, com predomínio na infância e adolescência e pico ao redor da puberdade. A doença parece incidir 
igualmente em ambos os sexos, com alguma preponderância do sexo feminino em determinadas populações de baixo risco (japonesa) e, do sexo masculino em outras populações com alta incidência da doença (Finlândia e Sardenha) (KARVONEN et al., 1997).

A prevalência do DM1 é inferior a 1\%, porém, observam-se grandes variações de incidência entre populações e áreas geográficas. As maiores taxas mundiais de incidência (superiores a 35/100.000 habitantes/ano) ocorrem na Finlândia e Sardenha, seguidas por populações caucasianas com incidência moderada da doença na Europa e América (cerca de 10-20/100.000 habitantes/ano). As menores taxas mundiais (inferiores a 3/100.000 habitantes/ano) são encontradas nos países asiáticos (Japão, China e Coréia) (KARVONEN et al., 1997). No Brasil observamos taxas ao redor de 7,6/100.000 habitantes/ano (FERREIRA et al., 1993).

Determinadas variações étnicas em populações residentes na mesma área geográfica podem acarretar riscos diferentes para progressão de DM1, conforme já observado em americanos de origem africana e hispânicos, apresentando menor incidência do que caucasianos residentes na mesma área (KARVONEN et al., 1993).

A incidência de DM1 tem aumentado mundialmente segundo estudos epidemiológicos, inclusive em populações com composição étnica homogênea, sugerindo a influência de fatores ambientais (MUNTONI et al., 1995).

A interação de fatores ambientais e genéticos parece ter papel fundamental no desenvolvimento do DM1.

\subsubsection{Fatores Genéticos}

O principal locus diabetogênico ou de susceptibilidade para o DM1, denominado IDDM-1 (40-50\% de risco para agregação familiar de DM1) encontra-se situado no braço curto do cromossomo 6 (p21.3) e corresponde ao locus dos antígenos do sistema HLA (Antígeno Leucocitário Humano), localizado no Complexo Principal de Histocompatibilidade (MHC: major histocompatibility complex) (NOBLE et al., 1996). 
A associação entre o sistema HLA com o DM1 foi inicialmente sugerida pela evidenciação dos antígenos de classe I (HLA-B8 e B15) por tipagem sorológica (NOBLE et al., 1996).

Posteriormente, por outras técnicas de tipagem e seqüenciamento de DNA, observou-se maior associação com moléculas HLA de classe II, especificamente as codificadas nos loci HLA-DR3 e HLA-DR4 e, principalmente, no locus HLA-DQ (JIN-XIONG, 1996).

Entre os alelos que codificam as moléculas de classe II no locus DR, HLADR3 ou HLA-DR4 são os mais presentes nos pacientes diabéticos (95\% contra 50\% dos controles caucasóides) e cerca de $55 \%$ a $60 \%$ destes pacientes são heterozigotos DR3/DR4 (contra 3\% dos controles), conferindo o maior risco para progressão da doença, seguido pela homozigose para DR4 e, finalmente, para DR3 (NERUP et al., 1987).

Existe um outro locus de susceptibilidade para DM1, denominado IDDM-2 localizado no cromossomo 11 (p5.5), em região denominada VNTR (variable number of tandem repeats), próxima a região $5^{\prime}$ final do gene da insulina. A associação do IDDM-2 com predisposição ao DM1 em populações não caucasianas, ou sua relação com ausência ou presença de alelos HLA de susceptibilidade são ainda controversas (OWERBACH \& GABBAY, 1993).

Os estudos para identificar os genes responsáveis pela susceptibilidade genética do DM1 sugerem a existência de pelo menos 15 loci localizados em diversos cromossomos.

As moléculas de classe I e II estão envolvidas com a resposta imune adaptativa pela apresentação de peptídeos patogênicos às células $T$. As moléculas de classe I do sistema HLA, expressas na maioria das células somáticas, estão envolvidas diretamente no processamento de antígenos sintetizados no citosol. Por outro lado, as moléculas de classe II são expressas em um grupo de células imunes, incluindo macrófagos, células dendríticas, epiteliais tímicas, células $\mathrm{T}$ ativadas e células $\mathrm{B}$, e atuam no processamento de proteínas das vesículas intracelulares (KLEIN \& SATO, 2000). 
As moléculas HLA de classe I ou classe II posicionam-se na superfície das células ligadas aos peptídeos antigênicos formando um complexo que será reconhecido pelos receptores de célula T (TCR: t-cell receptor) como próprios ou não-próprios, desencadeando a resposta imune adaptativa direcionada pelos co-receptores CD4 ou CD8, presentes na superfície da célula T (McDEVITT, 1995).

O TCR liga-se ao peptídeo ancorado à molécula HLA na fenda de ligação peptídica, e as glicoproteínas co-receptoras CD4 ou CD8 na superfície da célula T interagem com partes da molécula HLA externas à fenda, facilitando a adesão do TCR ao complexo molécula HLA-peptídeo. Esta ligação é muito frágil quando ocorre sem a presença das moléculas co-receptoras. A interação do TCR ao complexo molécula de classe I ou de classe II HLA-peptídeo, com alta especificidade na região de seu domínio variável (V), determina a expressão da molécula co-receptora CD8+ ou CD4+ e, conseqüentemente, a resposta imunológica a ser desenvolvida (JANEWAY et al., 2002).

O TCR que se liga ao complexo de molécula de classe I-peptídeo, geralmente determina maior expressão dos co-receptores $\mathrm{CD} 8(\mathrm{CD} 8+)$ e menor expressão das moléculas CD4 (CD4-). Complexos tri-moleculares compostos por moléculas de classe I, peptídeos e TCR identificam, portanto, células-alvo e, por intermédio de células T que se tornam $(\mathrm{CD} 8+)$ desencadeiam um ataque imunológico do tipo citotóxico às mesmas. O inverso ocorre após a interação do TCR e complexo moléculas de classe IIpeptídeo, onde as células CD4 tornam-se mais expressas (CD4+). O complexo composto por moléculas de classe II, peptídeos e TCR desencadeia resposta imune das células $\mathrm{T}$ como auxiliares (CD4+) com estímulo de macrófagos e de células $\mathrm{B}$, com conseqüente produção de anticorpos (JANEWAY et al., 2002).

\subsubsection{Fatores Ambientais}

A concordância de apenas 50\% para o desenvolvimento de DM1, em gêmeos monozigóticos, sugere fortemente a presença de fatores ambientais na etiopatogenia da doença (TATTERSALL \& PYKE, 1972). 
São, entretanto, controversos os mecanismos e os agentes que determinam a participação do meio ambiente na etiopatogenia do DM1. Diversos agentes etiológicos (vírus, alimentos, nitrosaminas e outros) têm sido sugeridos como possíveis desencadeadores da sensibilização do sistema imunológico e conseqüente perda da tolerância às proteínas específicas das ilhotas.

Infecções virais são componentes importantes no processo de desencadeamento da doença. A participação pode ser direta, com efeitos citolíticos ou, colaborando para a exacerbação de um processo crônico pré-existente. Os vírus associados ao desenvolvimento da doença em humanos pela infecção citolítica são do grupo Coxsackie A e pelo desencadeamento de fenômenos de auto-imunidade, estão os da caxumba, citomegalovírus, rubéola, Epstein-Barr e Coxsackie B4.

Após um período de latência entre 5 a 25 anos, cerca de 10 a $20 \%$ dos pacientes com rubéola congênita tornam-se diabéticos, decorrentes possivelmente da passagem transplacentária do vírus da mãe para o feto (YOON, 1993).

Os estudos com citomegalovírus e vírus da caxumba são inconclusivos e parecem apenas circunstanciais.

Enterovírus, principalmente Coxsackie B (CBV), parecem ter relação temporal direta com o aumento de incidência de DM1. Para alguns autores, as infecções sucessivas por diferentes sorotipos de CBV aumentam o risco para desenvolvimento de diabetes auto-imune em indivíduos geneticamente predispostos (HYOTY et al., 1995).

Na última década, as proteínas advindas do leite de vaca tem sido imputadas como um possível fator de risco para o aparecimento do DM1. Estudos epidemiológicos têm indicado maior risco de desenvolvimento de DM1 em indivíduos que ingeriram leite de vaca no período neonatal ou infância precoce. Em pacientes com diabetes recém-diagnosticado observaram-se níveis aumentados de anticorpos contra constituintes do leite de vaca, notadamente a albumina sérica bovina (BSA), que apresenta $87 \%$ de homologia com a humana em sua cadeia de aminoácidos, e a-ßlactoglobulina, que não é um componente endógeno do leite humano (MARTIN et al., 1992). 
Contrariamente a essa hipótese, foram, entretanto, encontrados esses anticorpos em parentes não-diabéticos de portadores de DM1 e, também, em pacientes com outras doenças auto-imunes (ATKINSON et al., 1993).

É razoável supor, portanto, que os auto-antígenos envolvidos com a resposta imunológica não têm necessariamente ação direta nesse processo, mas são induzidos como conseqüência de descontrole da tolerância oral do sistema imune intestinal.

Com relação as nitrosaminas, estudos demonstram que a freqüência da ingesta de alimentos contendo tais compostos tem relação com risco para DM1 (VIRTANEN et al., 1994).

Desta forma, a combinação de genes de susceptibilidade e fatores ambientais parece ser necessária para o início do fenômeno de autoimunidade.

\subsubsection{Auto-imunidade e os marcadores celulares}

As bases para a etiopatogenia auto-imune no DM1 provêm da presença de um infiltrado mononuclear ao redor das ilhotas (insulite) no pâncreas de pacientes falecidos logo após o diagnóstico da doença e da presença de anticorpos séricos dirigidos contra os componentes da célula- $\beta$ de indivíduos recém-diagnosticados.

Embora o antígeno específico da célula- $ß$ não esteja definido, tanto a agressão celular (linfócitos $\mathrm{T}$ citotóxicos e macrófagos) quanto a humoral [auto-anticorpos, e citoquinas, especialmente interleucina 1 (IL-1), interferon- $\gamma($ IFN- $\gamma$ ) e fator de necrose tumoral (TNF- $\alpha)$ ] parecem favorecer a lesão da célula- $\beta$.

A resposta imune do DM1 tem início quando ocorre um desequilíbrio nos mecanismos de tolerância aos antígenos próprios, com participação de ambas as moléculas co-receptoras CD4 e CD8. As células T-CD4 ativadas (CD4+) agem no processo da insulite, determinando reações inflamatórias e secreção de citoquinas, ou funcionando como células auxiliares para células T-CD8 e células B. As células TCD4+ podem ser classificadas em dois sub-grupos de acordo com seu perfil secretório de citoquinas e função efetora: 
Células T auxiliar ou helper 1 (Th-1) que secretam IFN- $\gamma$, TNF- $\alpha$, TNF- $\beta$, IL-2 e IL-3 associadas à imunidade celular (hipersensibilidade tardia).

Células T auxiliar ou helper 2 (Th-2): envolvidas com a secreção de IL-4, IL-5, IL-6, IL-10 e IL-13 associadas predominantemente, com a imunidade humoral e alergia.

As citoquinas IL-1 e TNF- $\alpha$ são produzidas por macrófagos e monócitos, promovendo ação pró-inflamatória pela estimulação de fagócitos, aumento de permeabilidade vascular, quimiotaxia e produção de radicais livres.

O IFN- $\gamma$ induz a síntese de receptores de TNF- $\alpha$ e aumenta a produção de IL-1 e TNF- $\alpha$ pelos macrófagos, os quais induzem a liberação de IL-2 e IFN- $\gamma$ pelas células T. IFN- $\gamma$ aumenta a expressão de antígenos de classe I nas células, facilitando a ação das células T citotóxicas sobre as células alvo. Eles, também, induzem a expressão de antígenos de classe II MHC nos macrófagos e de moléculas de adesão nas células endoteliais e apresentadoras de antígenos (APC: antigen presenting cell) .

Como o IFN- $\gamma$ é produzido, principalmente, por sub-grupos de células T (Th-1) e a IL-4 e IL-10 são produtos de sub-grupos Th-2, tem sido sugerido que o diabetes auto-imune se desenvolve em indivíduos geneticamente susceptíveis quando ocorre um desequilíbrio entre os efeitos Th-1 e Th-2. Tanto IL-4 como IL-10 suprimem a produção de IFN- $\gamma$, implicado no processo de destruição das células- $\beta$. A expressão de autoimunidade é regulada por IL-4 e IL-10 produzidas nas células T, e o balanço entre os tipos de citoquinas secretadas resulta em uma resposta destrutiva ou não das células alvo (RABONOVITCH, 1994).

Citoquinas, como IL-1 e IFN- $\gamma$, podem agir diretamente nas células- $\beta$ das ilhotas ou, por intermédio da produção de radicais livres, são capazes de causar danos ao DNA, enzimas, e membranas biológicas (MANDRUP-POULSEN et al., 1985). As células- $\bigcap$ são altamente sensíveis a danos causados por radicais de oxigênio livre, devido à sua alta taxa metabólica e baixa atividade de sistemas carreadores de radicais livres. 


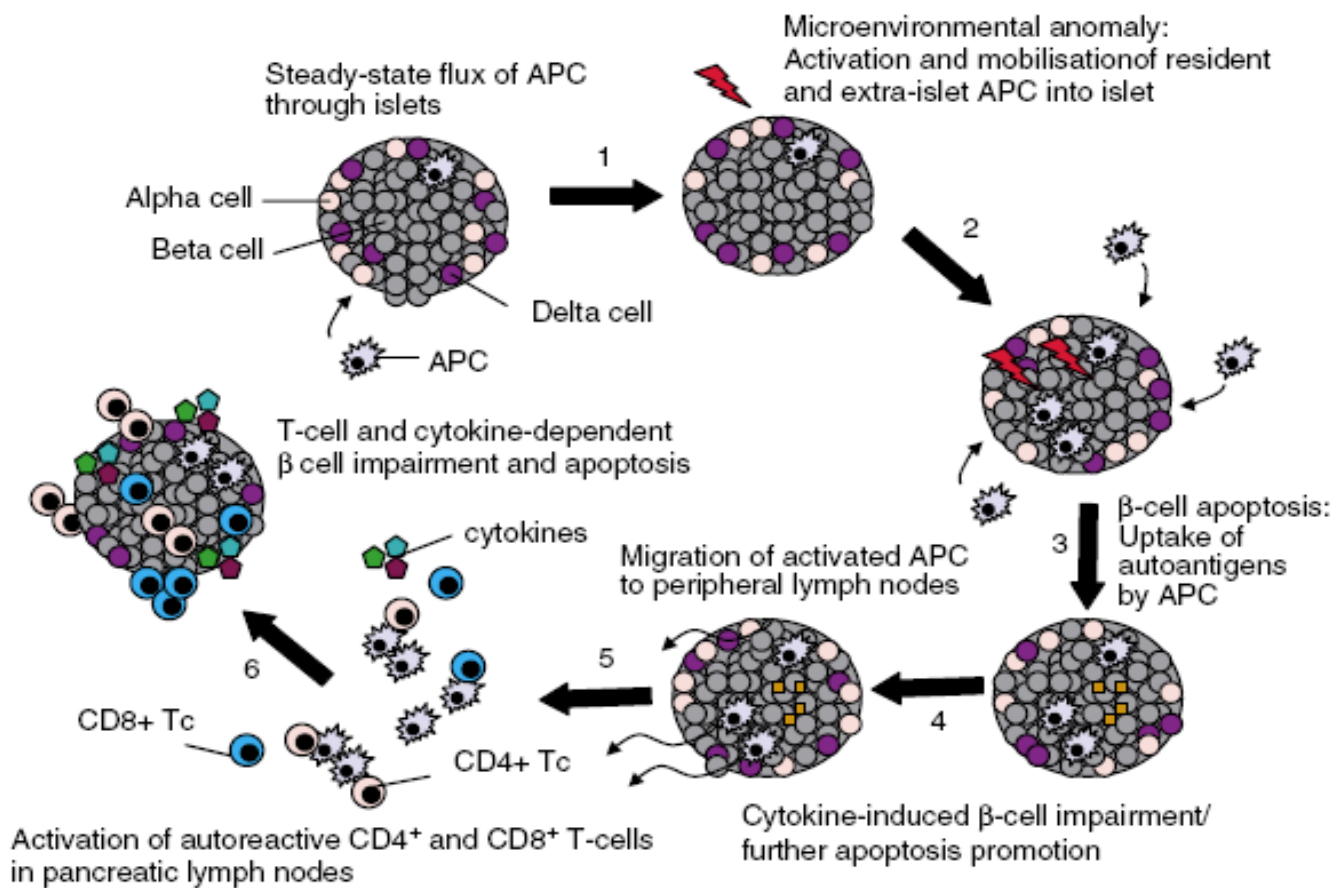

Figura 1: Processo multi-etapas da insulite: Durante o desenvolvimento ontogenético, as populações de timócitos cujos TCR reconhecem os antígenos específicos da célula- $\beta$, são desativadas no timo ou deixam de ser toleradas na periferia. Estas células $T$, circulam de forma queiscente ou ativa e podem ser suprimidos pela rede regulatória de células $\mathrm{T}$. As células apresentadoras de antígenos (dendríticas ou macrófagos) residentes nas ilhotas, vigiam o micro-ambiente. As anormalidades do microambiente, ainda não identificadas, convertem o fenótipo destas células em ativadores da resposta inflamatória durante sua migração do ambiente insular para os órgãos linfóides periféricos, onde encontram finalmente as células $\mathrm{T}$ reativas. Enquanto isto, observa-se a progressão do processo inflamatório dentro da ilhota devido à secreção pelos macrófagos e células dendríticas, de mediadores solúveis da ativação da apoptose e da disfunção da célula-ß. (Bottino R, Lemarchand P, Trucco M and Giannoukakis N. Gene- and cell-based therapeutics for type I diabetes mellitus. Gene Therapy v.10, p.875-889, 2003). 
Os marcadores humorais mais freqüentes de agressão imune são: anticorpos anti-insulina (IAA), anticorpos anti-ilhotas de Langerhans citoplasmático (ICA), anticorpos anti-enzima descarboxilase do ácido glutâmico (anti-GAD) e anticorpos anti-proteína de membrana com homologia às tirosino-fosfatases (anti-IA-2). Títulos elevados e combinados destes auto-anticorpos têm alto valor preditivo para a progressão da doença (VERGE et al., 1996).

O anticorpo anti-ilhota de Langerhans citoplasmático (ICA) foi o primeiro auto-anticorpo caracterizado por técnica de imunofluorescência em cortes de pâncreas humano congelado, em pacientes com doença poliendócrina auto-imune e DM1 (BOTAZZO et al., 1974) . O ICA é um auto-anticorpo sensível e específico para DM1, presente em cerca de $60-90 \%$ dos pacientes recém diagnosticados, e em menos de $5 \%$ dos indivíduos normais. Seu valor preditivo está associado diretamente a títulos elevados e persistentes. Não é dirigido contra um antígeno específico das células- $\beta$, podendo indicar perda de tolerância imunológica a uma ou várias estruturas celulares ao mesmo tempo (GENOVESE et al., 1992). O ICA desaparece na maioria dos pacientes com DM1 dentro de 2 a 3 anos após o início da doença. No entanto, 10-15\% dos indivíduos persistem com títulos positivos após esse intervalo (KOLB et al., 1988).

Palmer e cols. em 1983 observaram a presença de anticorpos contra insulina em pacientes diabéticos, antes da terapêutica insulínica. As concentrações dos anticorpos anti-insulina (IAA) tem correlação inversa com a idade, apresentando níveis mais elevados em crianças menores do que 5 anos de idade. Anticorpos anti-insulina (IAA) podem estar presentes em mais de 50\% dos pacientes portadores de DM1 recémdiagnosticados até os 5 anos de idade. Os títulos de IAA declinam com a idade em contraste com o ICA (THAI \& EINSENBARTH, 1993).

A enzima descarboxilase do ácido glutâmico (GAD), necessária para a biossíntese do ácido $\gamma$-amino butírico, é encontrada em vários tecidos extra-neurais, incluindo células-ß. Em 1990, esta enzima foi identificada como um dos antígenos mais importantes no desenvolvimento do DM1 (BAEKKESKOV et al., 1990). A dosagem de anticorpos anti-GAD parece ser o procedimento de escolha para "screening" de indivíduos que possam vir a desenvolver a doença, assim como confirmar a autoimunidade como fator responsável pelo aparecimento da doença. 
Níveis de anti-GAD podem tornar-se positivos até 10 anos antes da manifestação clínica da doença (TUOMILEHTO et al., 1994).

Paradoxalmente, altos títulos de anti-GAD estão associados a uma menor taxa de aparecimento da doença (10\% em 4 anos) quando comparados a títulos baixos (50\% em 4 anos), posssivelmente porque altos títulos indicariam preferencialmente maior ativação humoral e menor ativação da resposta imune celular (HARRISON et al., 1993).

$\mathrm{O}$ rastreamento de uma biblioteca de cDNA isolado de insulinoma humano permitiu identificar uma proteína denominada antígeno da Ilhota 2 (IA-2), pouco maior que ICA-512, contendo todos seus epítopos. Esta proteína IA-2/ICA512 apresenta homologia com proteínas tirosino-fosfatases, e apesar de sua função não estar definida, talvez tenha atuação no sinal de internalização de componentes da membrana vesicular (LAN et al., 1994).

A freqüência de títulos positivos de anti-IA2 em crianças com diagnóstico recente de DM1 é de aproximadamente $60-80 \%$ e inferior a $2 \%$ em indivíduos não diabéticos. Estas taxas são maiores em crianças com aparecimento da doença entre 510 anos de idade (67\%) quando comparadas a crianças menores de 5 anos (55\%) e crianças com idade variando entre 10-15 anos (57\%) (FEENEY et al., 1997).

O DM1 é desencadeado por reações anômalas do sistema imunológico contra antígenos específicos do pâncreas. Os linfócitos $\mathrm{T}$ autoreativos são os principais protagonistas da resposta inflamatória destrutiva contra o pâncreas. Os auto-anticorpos direcionados contra antígenos pancreáticos, determinados pela ativação dos linfócitos B, podem ser considerados marcadores pré-clínicos do DM1. Durante os primeiros anos do acometimento, os títulos altos de múltiplos auto-anticorpos podem ser sinais precoces de rápida progressão da doença com deterioração da função pancreática (BORG et al., 2001).

Devido ao fato dos auto-anticorpos estarem presentes ao diagnóstico em mais de $90 \%$ dos casos e o número de anticorpos positivos estar relacionado ao risco aumentado dos parentes de $1^{\mathrm{o}}$ grau de pacientes diabéticos em desenvolver DM1, sugere-se que o perfil dos auto-anticorpos possa distinguir alta e baixa atividade da doença, refletindo o estado imunoregulatório do DM1 (BINGLEY et al., 1997; KULMALA et al., 1998). 


\subsection{Sistema GH-IGF-IGFBP}

\subsubsection{Fatores de Crescimento Insulina-Símile (IGFs)}

Em 1957, SALMON \& DAUGHADAY observaram por estudos "in vitro", que a incorporação de sulfato ao tecido cartilaginoso induzida pelo hormônio de crescimento $(\mathrm{GH})$ ocorria de forma indireta, por mediadores GH-dependentes. Inicialmente denominados de somatomedinas, estes mediadores foram caracterizados como dois peptídeos distintos que apresentam atividade insulina-símile e estrutura molecular homóloga à pró-insulina, nas regiões que correspondem às cadeias $\mathrm{A}$ e $\mathrm{B}$ da insulina, resultando na nomenclatura atual de fatores de crescimento insulina-símile tipos I e II (IGF-I e IGF-II).

Os IGF-I e IGF-II constituem peptídeos anabólicos de cadeia única, estruturalmente semelhantes, que apresentam homologia de $62 \%$ e atuam de maneira sistêmica ou como reguladores locais da proliferação, diferenciação, função e sobrevida de diversas células do organismo.

O IGF-I é uma proteína de aproximadamente 7,5 kDa formado por uma cadeia linear composta de 70 aminoácidos, codificado por um gene único localizado no braço longo do cromossomo 12. O locus para o IGF-II está situado no braço curto do cromossomo 11, próximo ao gene da insulina. Ambos apresentam cerca de 43\% de homologia com a pró-insulina e estão presentes no plasma de adultos em quantidades que variam nos adultos de 100 a $200 \mathrm{ng} / \mathrm{mL}$ para o IGF-I e 600 a $650 \mathrm{ng} / \mathrm{mL}$ para o IGF-II, geralmente associados à proteínas de ligação (IGFBPs) capazes de modular suas ações biológicas (SARA \& HALL, 1990).

O fígado constitui a maior fonte do IGF-I e IGF-II circulantes. A concentração sérica do IGF-I é baixa ao nascimento aumentando gradualmente até a puberdade e diminuindo progressivamente na vida adulta como resultado da secreção atenuada do GH. (ROSENFELD, 1996).

Os conhecimentos relativos à regulação do eixo somatotrófico vêm sendo modificados ao longo do tempo. Os estudos iniciais sugeriam que o IGF-I mediaria a ação do GH no processo de crescimento, sem qualquer evidência da ação direta do GH 
ou da produção local de IGF-I neste processo. Posteriormente, demonstrou-se a importância do IGF-I produzido localmente, assim como do papel do GH agindo diretamente (não mediado por IGFs) no crescimento somático. Estas observações demonstram que o $\mathrm{GH}$ atua de forma direta e indireta no processo e reforça a importância da produção local do IGF-I (ação autócrina/parácrina) (LE ROITH et al., 2001).

Diversos estudos revelam, entretanto, uma maior complexidade da ação do sistema GH/IGF, envolvendo múltiplos níveis de interação com as suas proteínas de ligação (RECHLER, 1993).

Dados provenientes de estudos em camundongos "knock-out" para o IGF-I hepático, demonstrando crescimento e desenvolvimento praticamente normal destes animais, apesar de importante redução nos níveis de IGF-I e IGFBP-3 circulantes e aumento do GH, questionam o real papel do IGF-I circulante nestes processos. Os níveis de IGF-I livre encontram-se dentro da normalidade e devem estar envolvidos neste processo, juntamente com o efeito autócrino/parácrino do IGF-I (SJOGREN et al., 1999).

O GH e o estado nutricional são os maiores reguladores da expressão tecidual do IGF-I. A administração de GH em ratos hipofisectomizados induz um aumento na expressão hepática do IGF-I equivalente a 30 vezes e contribui para o efeito endócrino deste peptídeo. Outros hormônios tróficos como o hormônio adrenocorticotrófico $(\mathrm{ACTH})$, tireoestimulante (TSH) e prolactina (PRL) podem estimular a produção local de IGF-I em diversos tecidos, sustentando seu papel autócrino e parácrino (UNDERWOOD \& VAN WYK, 1992).

Em indivíduos saudáveis sob condições fisiológicas, a insulina secretada pelas células- $ß$ alcança o fígado pelo sistema porta, local em que concentração de insulina é bastante elevada quando comparada a sua concentração na periferia (POLONSKY et al., 1988).

A concentração insuficiente de insulina no sistema porta, observada nos pacientes diabéticos tipo 1, promove resistência hepática ao $\mathrm{GH}$ e aumento da produção de IGFBP-1 (BERKET et al., 1999). A resistência ao GH resulta em 
diminuição da produção hepática de IGF-I, IGFBP-3 e altera o "feed-back" negativo IGF-I/GH, promovendo secundariamente hipersecreção de GH (BERKET et al., 1999).

Em pacientes diabéticos tipo 1 sem secreção endógena de insulina, a concentração de IGF-I é 30-40\% inferior quando comparada a população de referência e mostrou não estar relacionada ao controle glicêmico (EKMAN et al., 2000).

No entanto, existem dados contrários demonstrando que a melhora do controle glicêmico por insulinoterapia intensiva leva a um aumento dos níveis de IGF-I, bem como da velocidade de crescimento dos pacientes estudados (TAMBORLANE, 1981).

A administração intra-peritoneal de insulina promove aumento dos níveis plasmáticos de IGF-I, sugerindo que as baixas concentrações observadas em pacientes diabéticos tipo 1 , em uso de insulinoterapia subcutânea, seja secundária a hipoinsulinemia portal (HANAIRE-BROUTIN et al., 1996).

Existem diversos achados na literatura sobre a produção local de IGF-I pelos tecidos linfóides. Os mecanismos envolvidos na regulação desta produção assim como a sua importância, permanecem, entretanto, pouco esclarecidos. Diversas citoquinas (TNF- $\alpha$, PGE2, IFN- $\gamma$, etc.) parecem atuar diretamente, estimulando ou inibindo a produção local de IGF-I pelas células linfóides (CLARK, 1997). Desta forma, os linfócitos estão expostos a ação do IGF-I circulante, IGF-I autócrino e talvez de forma mais importante, à ação do IGF-I produzido nas células epiteliais e estromais do tecido linfóide primário (timo e medula óssea) (CLARK, 1997).

Estudos experimentais recentes, analisando o desenvolvimento e a função dos linfócitos em camundongos geneticamente defeituosos na expressão desses hormônios ou de seus respectivos receptores, questionam o verdadeiro papel destes hormônios na regulação da resposta imune.

O camundongo "Snell Dwarf" (dw/dw) foi inicialmente descrito em 1929 e apresenta deficiência primária de prolactina, GH e TSH, devido a uma mutação no fator de transcrição pit-1, necessário para o desenvolvimento normal da hipófise. Secundariamente, ocorre um prejuízo na biossíntese destes hormônios e conseqüente deficiência dos mesmos, assim como de IGF-I, T3 e T4 (LI et al., 1990). 
O camundongo lit/lit foi inicialmente descrito por Eicher e Beamer em 1976 e é caracterizado pela deficiência de aproximadamente 90\% dos níveis de GH séricos, resultando na supressão de 90-95\% dos níveis de IGF-I circulantes. O defeito autossômico recessivo nestes animais é secundário a uma mutação de um único nucleotídeo no gene do receptor de GHRF (Growth Hormone Release Factor). Como resultado, os somatotrofos perdem a capacidade de produzir $\mathrm{GH}$, já que não ocorre a ligação do GHRF com o seu respectivo receptor (LIN et al., 1993).

Os estudos em animais geneticamente modificados para a codificação do gene do IGF-I ou do seu receptor (IGF-IR), são prejudicados, já que grande parte dos homozigotos (IGF-I -/-) morrem logo após o nascimento por problemas respiratórios relacionados ao desenvolvimento deficiente do diafragma (LIU et al., 1993).

Em animais lit/lit e IGF-I -/- o desenvolvimento das linhagens de células B, assim como o número absoluto de células quando corrigidos para o tamanho do animal, não apresentaram, entretanto, diferenças em relação a população controle. Estes achados, associados ao fato de que tanto a administração de GH quanto de IGF-I não restauram a normalidade da linfopoese de células $B$ em camundongos $\mathrm{dw} / \mathrm{dw}$, sugerem que estes hormônios não estejam implicados obrigatoriamente neste processo (MONTECINO-RODRIGUEZ et al., 1997).

No processo de timopoese os dados da literatura são, porém, bastante controversos. Os trabalhos iniciais que avaliaram a timopoese em camundongos $\mathrm{dw} / \mathrm{dw}$ e ratos hipofisectomizados demonstraram involução precoce da glândula e diminuição importante do número de células (BARONI, 1967; SMITH, 1930),

Outros estudos realizados em camundongos dw/dw, lit/lit e IGF-I -/- mostram, entretanto, que a expressão de subpopulações CD4 ou, também, CD8 pelos timócitos, bem como a celularidade ajustada para o tamanho e o peso destes animais, não difere do grupo controle (MONTECINO-RODRIGUEZ et al., 1997).

Similarmente, não se observou alterações tanto da resposta imune humoral (tardia) quanto inata (precoce) de camundongos lit/lit infectados pelo vírus LCMV (Lymphocitic Choriomeningitis Vírus) ou pela LM (Listeria Monocytogenes), sugerindo que ambas as respostas independem de GH ou, também, do IGF-I (FOSTER et al., 2000). 
Muito embora todas estas observações possam sugerir fortemente, que tanto GH quanto IGF-I não sejam essenciais para o desenvolvimento e funcionamento das células responsáveis pela resposta imune, a literatura é bastante vasta em observações sobre o envolvimento destes fatores de crescimento nos mecanismos de regulação da resposta imunológica.

O IGF-I atua diretamente na proliferação e diferenciação de diversos tipos celulares como fator de progressão do ciclo celular. O tratamento de células em cultura utilizando o IGF-I e a adição de um fator de competência permitem que células quiescentes (G0) avancem para fase G1 e fases sucessivas do ciclo celular resultando na síntese de DNA e conseqüente proliferação celular. Seu efeito mitogênico foi observado em fibroblastos, condrócitos, células de músculo liso, linfócitos T e B e várias linhagens de células neoplásicas (JARDIEU et al., 1994; JONES \& CLEMMONS, 1995).

O IGF-I apresenta ação importante sobre as células linfóides e o sistema imune. A administração "in vivo" de IGF-I recombinante em camundongos, resultou no aumento significativo de células da linhagem $B$, sugerindo a ação combinada deste fator com a interleucina 7 na proliferação de linfócitos B (LANDRETH et al., 1992).

Ensaios “in vitro" utilizando linfócitos T estimulados pelo IGF-I, mostraram aumento da incorporação de timidina dose-dependente e um maior índice de proliferação destas células na presença de fitohemaglutinina (ROLDAN et al., 1989). O IGF-I induz a secreção de timulina pelas células epiteliais do timo revertendo à atrofia deste orgão em ratos hipofisectomizados e aumentando a proliferação dos linfócitos T CD4 e CD8 (KELLEY et al., 1996).

Complementar à sua ação sobre a proliferação e função celulares, o papel do IGF-I e de seu receptor na inibição da apoptose vêm sendo bem caracterizado, constituindo um mecanismo importante na regulação da produção e sobrevida das células sanguíneas normais e neoplásicas. A ação do IGF-I na supressão da apoptose parece estar relacionada à fosforilação de mediadores citosólicos cuja síntese é regulada por outros fatores de crescimento (RUBIN \& BASERGA, 1995).

Os IGFs podem, portanto, agir aumentando a sobrevida de diversos tipos de células limitando o mecanismo de apoptose. Os mecanismos pelos quais os IGFs são 
capazes de proteger esse fenômeno ainda não estão estabelecidos e parecem ser variados.

O perfeito entendimento do papel do GH/IGF-I na resposta imune provavelmente está em conciliar todos estes dados com os achados obtidos pelos estudos em animais geneticamente modificados (dw/dw, lit/lit, IGF-I -/-).

Desta forma, é razoável supor que tanto GH quanto IGF-I atuariam primariamente como promotores e mediadores de crescimento, com ação sobre múltiplos sistemas, incluindo o sistema imune.

Em última instância, a administração de GH/IGF-I poderia ser benéfica durante o processo de envelhecimento. Sabidamente seus níveis declinam com a idade, podendo levar indiretamente a prejuízos em determinados órgãos e sistemas, incluindo uma maior susceptibilidade a determinadas doenças, justificando talvez nestes casos a sua utilização de forma bastante criteriosa.

\subsubsection{Receptor para o IGF-I (IGF-IR)}

A ação dos IGFs envolve um sistema complexo dependente da presença de receptores específicos para o IGF-I (IGF-IR) e IGF-II (IGF-IIR), da modulação por proteínas de ligação (IGFBPs) e da participação de proteases que regulam a afinidade dos IGFs pelas IGFBPs.

Estruturalmente, o IGF-IR é uma glicoproteína com peso molecular de $350 \mathrm{kDa}$ codificada a partir de um gene localizado no cromossomo 15. É formado por duas subunidades- $\alpha$ extra-membrânicas compostas por 706 aminoácidos cada e duas subunidades- $\beta$ transmembrânico-citoplasmáticas compostas por 627 aminoácidos unidas por pontes dissulfeto formando um complexo heterotetramérico $(\beta-\alpha-\alpha-\beta)$ que caracteriza o receptor funcional.

A ligação com o IGF-I ocorre no domínio rico em cisteínas da subunidade- $\alpha$ e leva a autofosforilação do domínio tirosina-quinase da subunidade- $ß$. Seguem-se uma série de eventos que ativam moléculas sinalizadoras citosólicas e nucleares por fosforilação e defosforilação de substratos intracelulares resultando na transcrição (ou 
modificações pós-transcricionais do mRNA) e expressão do produto dos genes reguladores da ação do IGF-IR.

Os IGF-IR estão largamente distribuídos nas células do organismo e são regulados por outros fatores de crescimento que atuam combinados ou não ao IGF-I estimulando seu efeito biológico. Hormônios hipofisários como o luteinizante $(\mathrm{LH})$ e folículo estimulante $(\mathrm{FSH})$ induzem um aumento da expressão do IGF-IR. Fatores de crescimento como o PDGF (fator de crescimento derivado de plaquetas) e FGF (fator de crescimento para fibroblastos) são considerados fatores de competência, pois atuam promovendo a expressão do IGF-IR em diversas células tornando-as sensíveis à ação do IGF-I capaz de permitir a replicação do DNA e a proliferação celular.

A presença do IGF-IR tem sido documentada em todas as linhagens hematopoéticas normais suportando a ação do IGF-I na eritropoese, granulopoese e linfopoese (SHIMON \& SHPILBERG, 1995).

Experimentos realizados com células embrionárias de camundongos desprovidas do IGF-IR, mostraram que 90\% das células foram incapazes de proliferar mesmo quando o meio de cultura era suplementado com outros fatores de crescimento. Estas observações demonstram a importância do receptor no processo de replicação e diferenciação celular (REISS et al., 1992).

O IGF-IR tem a capacidade de enviar sinais contraditórios para as células, agindo por mecanismos anti-apoptóticos e estimuladores de diferenciação celular, ou então, prejudicando o crescimento tecidual e conseqüentemente levar a morte destas células. A escolha entre estas duas vias de sinalização depende da quantidade e do tipo de substrato intracelular disponível. Na ausência de IRS-1 (ou em baixas concentrações), o IGF-IR estimula a via apoptótica. Contrariamente, o aumento da expressão do IRS-1 promove não apenas a diferenciação celular, como, também, a capacidade de transformação destas células. Estes efeitos contraditórios devem ser avaliados criteriosamente para o correto entendimento do papel do IGF-IR nestes processos (VALENTINIS \& BASERGA, 2001). 


\subsubsection{Proteínas de Ligação dos IGFs (IGFBPs)}

Atualmente foram identificadas dez tipos estruturalmente diferentes de IGFBPs, podendo ser divididas em dois subgrupos: um de alta afinidade para ligação com os IGFs (IGFBPs de 1 a 6) e outro formado por quatro proteínas de ligação relacionadas (IGFBP-rP) com baixa afinidade para o IGF-I (KIM et al., 1997). As IGFBP-rP 7 e 8 codificadas por dois genes denominados, respectivamente, de MAC25 e fator de crescimento do tecido conectivo (CTGF), apresentam homologia ao redor de $30 \%$ com as demais IGFBPs e suas implicações vem sendo investigadas (ROSENFELD, 1996).

As IGFBPs atuam no transporte dos IGFs da circulação para os tecidos periféricos, como reservatório circulante de IGFs, potencializando ou inibindo a ação dos IGFs ou ainda mediando efeitos biológicos independentes dos IGFs (CLAIRE et al., 1996).

A proteína de ligação mais abundante no adulto é a IGFBP-3, uma proteína formada por 264 aminoácidos, com peso molecular de $29 \mathrm{kDa}$ na forma não glicada, que conjugada à uma subunidade ácido lábil (ALS) forma um complexo ternário de 150 kDa com o IGF-I. Este complexo é responsável em manter os níveis normais de IGF-I na circulação, prolongando sua meia vida de $30 \min$ para 12 a $15 \mathrm{~h}$ e protegendo-o contra degradação (SPAGNOLI \& ROSENFELD, 1997).

As concentrações séricas de IGFBP-3 variam nos adultos de 1,7 a 5,5 $\mu \mathrm{g} / \mathrm{mL}$, são reguladas diretamente pelo $\mathrm{GH}$ e aumentam com a idade, atingindo níveis máximos na puberdade em ambos os sexos.

Além destes efeitos na circulação periférica, as IGFBPs podem agir, também, de forma autócrina/parácrina.

Associadamente ao efeito de modulação entre os IGFs e o IGF-IR, as IGFBPs estão envolvidas nos mecanismos de adesão e motilidade celular, assim como nos processos de apoptose e sobrevida celular (FIRTH \& BAXTER, 2002).

Estudos utilizando cultura de fibroblastos transfectadas com o DNA complementar da IGFBP-3, demonstraram que esta proteína apresentava um efeito inibitório sobre proliferação celular. Sua ação anti-proliferativa independente do IGF-I 
foi, também, observada em tumores de mama sugerindo a presença de receptores específicos para a IGFBP-3 (BACH et al., 1995).

Contrariamente, a IGFBP-3 também pode apresentar efeitos pró-apoptóticos. Foi demonstrado em células PC3 de carcinoma prostático, um incremento da taxa de apoptose após a administração exógena de IGFBP-3 recombinante (RAJAH et al., 1997).

O fator de supressão tumoral p53 está envolvido diretamente na regulação da expressão de diversos genes relacionados aos mecanismos de proliferação e apoptose celulares. A inter-relação entre a IGFBP-3 e o p53 foi identificada em diversas neoplasias do tubo digestório, incluindo tumores de esôfago e cólon (HOLLOWOOD et al., 2000; BUCKBINDER et al., 1995).

Estes achados sugerem fortemente que a IGFBP-3 agiria como mediadora do processo de apoptose via p53 em resposta ao estresse celular, podendo agir diretamente ou pelo seqüestro dos IGFs.

Dados recentes sugerem que as IGFBPs podem exercer suas funções independentemente de suas ligações com os IGFs ou IGF-IR. Estes efeitos parecem ser mediados por fragmentos proteolizados ou intactos das IGFBPs envolvidos na estrutura da proteína. (FIRTH \& BAXTER, 2002).

Outras IGFBPs (IGFBP-1, IGFBP-2 e IGFBP-4) são capazes de atravessar a barreira endotelial transportando o IGF-I do sangue para os tecidos adjacentes, conferindo um efeito modulador à ação endócrina deste fator.

Foi demonstrado que a IGFBP-1 estaria envolvida nos mecanismos de apoptose de células de carcinoma mamário, pela defosforilação da via FAK (FIRTH \& BAXTER, 2002).

Estes achados, bem como a expressão de IGFBP-1 em tecido endometrial durante a fase secretória do ciclo menstrual, sugerem que ela esteja presente nos mecanismos de apoptose e remodelação (IRWIN et al., 2001).

As IGFBPs estão sujeitas à ação de proteases capazes de alterarem suas propriedades físico-químicas envolvidas na ligação com os IGFs, modulando indiretamente a ação destes fatores (SARA \& HALL, 1990; BACH et al., 1995). 
O soro de gestantes apresentou aumento da atividade proteolítica contra IGFBP-3 reduzindo sua afinidade de ligação ao IGF-I. A presença de proteases foi, também, observada em outras condições como doenças graves, pós-operatório e situações de estresse (SHIMON \& SHPILBERG, 1995).

A importância do complexo IGF-IGFBPs na regulação do crescimento celular está bem estabelecida, porém sua atuação nos mecanismos de sobrevida/morte celular permanece ainda obscura. Existem dados suficientes demonstrando, entretanto, sua interação com vias relacionadas aos processos de apoptose e proliferação celular, em múltiplos níveis e diferentes tecidos.

Devido à sua destacada importância no controle da proliferação celular e resposta imune, os componentes do sistema GH-IGF-IGFBP poderiam participar dos mecanismos imunoregulatórios do DM1 recém-diagnosticado. A magnitude de expressão do IGF-IR nos linfócitos T e B poderia refletir o estado imunoregulatório no DM1. 


\section{OBJETIVOS}

Baseado nas evidências da literatura sobre o provável papel do sistema GHIGF-IGFBP nos mecanismos imunológicos do DM1, este estudo tem como objetivos:

- Investigar a expressão do receptor do IGF-I em linfócitos T e B periféricos de pacientes portadores de DM1 em diferentes fases do diagnóstico pela determinação semi-quantitativa da expressão de seu mRNA pela metodologia de RT-PCR.

- Correlacionar os níveis plasmáticos de diferentes componentes do sistema GH-IGF-IGFBP e marcadores imunológicos humorais do DM1 (ICA, antiGAD e anti-IA2) com a expressão do IGF-IR nos linfócitos $\mathrm{T}$ e $\mathrm{B}$ de pacientes portadores de DM1 nas diferentes fases do diagnóstico. 


\section{CASUÍSTICA E MÉTODO}

\subsection{Casuística}

Os experimentos foram realizados em amostras de sangue periférico obtido de três subgrupos de indivíduos:

Grupo A: Representado por 7 pacientes diabéticos (5F:2M), pré-púberes (Tanner I), com até 6 meses de diagnóstico de DM1, sem evidência de qualquer outro acometimento clínico.

Grupo B: Representado por 16 pacientes diabéticos (12F:4M), pré-púberes (Tanner I), com diagnóstico de DM1 há mais de 6 meses, sem evidência de qualquer outro acometimento clínico.

Grupo C: Representado por 10 indivíduos sadios "Grupo Controle" (5F: 5M), pré-púberes (Tanner I).

Os pacientes dos grupos A e B foram selecionados do Ambulatório de Diabetes do Instituto da Criança (ICr) do Hospital das Clínicas da Faculdade de Medicina da Universidade de São Paulo (HC-FMUSP).

Os pacientes do Grupo $\mathrm{C}$ foram selecionados do Laboratório de Análises Clínicas Cimerman por procura espontânea para realização de exames pediátricos de rotina.

Todos os responsáveis legais pelos pacientes assinaram o consentimento esclarecido, após serem informados sobre o propósito e os riscos inerentes aos procedimentos experimentais necessários a consecução da investigação. $\mathrm{O}$ projeto de 
pesquisa foi submetido e aprovado pelas Comissões de Ética para análise de pesquisa do Hospital das Clínicas e Instituto da Criança.

\subsection{Processamento das Amostras}

De cada paciente ou indivíduo sadio, foram coletadas duas amostras de sangue periférico.

Um tubo contendo $10 \mathrm{~mL}$ de sangue periférico com heparina $(5000 \mathrm{UI} / \mathrm{mL})$ foi encaminhado para extração do mRNA para posterior análise da expressão do gene do IGF-IR pela técnica de RT-PCR semi-quantitativa. Este procedimento foi realizado no Laboratório de Endocrinologia Celular e Molecular-LIM 25/FMUSP.

O segundo tubo contendo $08 \mathrm{~mL}$ de sangue periférico com EDTA foi encaminhado para realização de hemograma completo e em seguida centrifugado.

O plasma obtido deste último tubo foi encaminhado para as determinações ou dosagens de: GH, IGF-I total, IGFBP-2, IGFBP-3, frutosaminas, peptídeo C, anticorpo anti-ilhota de Langerhans citoplasmático (ICA), anticorpo anti-tirosina fosfatase (antiIA2) e anticorpo anti-descarboxilase do ácido glutâmico (anti-GAD).

Estas dosagens foram realizadas na CRIESP (Central de Radioimunoensaio de São Paulo Ltda.).

\subsection{Metodologia}

Dos $10 \mathrm{~mL}$ de sangue coletados com heparina, foram isoladas as células $\mathrm{T}$ e $\mathrm{B}$ conforme método descrito a seguir. Os linfócitos $\mathrm{T}$ e $\mathrm{B}$ após separação, foram armazenados em TRIZOL $®$ para posterior extração do mRNA e avaliação da expressão do gene do IGF-IR pela técnica de RT-PCR semi-quantitativo. 


\subsubsection{Separação Negativa de Células}

\subsubsection{Separação das células mononucleares (MNC)}

A primeira etapa do método consistiu na separação de células mononucleares por gradiente de densidade, utilizando Lymphoprep ( $\mathrm{d}=1077$ ) (Nycomed Pharma AS, Oslo, Noruega).

O volume de sangue coletado foi diluído em solução salina na proporção de 1:2. Esta diluição foi distribuída com pipeta Pasteur em tubos de ensaio de $10 \mathrm{~mL}$ contendo aproximadamente $3 \mathrm{~mL}$ de Lymphoprep. Os mesmos foram centrifugados (Centrífuga Refrigerada Eppendorf 5810R, Hamburg, Alemanha) a 2.000 rpm, 30 min, $4^{\circ}$ C. Após centrifugação, obtivemos por gradiente de densidade um anel (nuvem) composto por células mononucleares, que foi removido com pipeta Pasteur e transferido para outro tubo. Completamos o volume com tampão fosfato salina $0,1 \%$ albumina sérica bovina (PBS/0,1\% BSA) e centrifugamos (Centrífuga Refrigerada Eppendorf 5810R, Hamburg, Alemanha) a $225 \mathrm{~g}, 8 \mathrm{~min}, 4^{\circ} \mathrm{C}$.

O sobrenadante foi desprezado, ficando apenas o botão celular, que foi ressuspendido em $10 \mathrm{~mL}$ de $\mathrm{PBS} / 0,1 \%$ BSA. Este procedimento foi realizado três vezes e após a última lavagem, o botão celular foi ressuspendido em $200 \mu \mathrm{L}$ de PBS $/ 0,1 \%$ BSA, e as células contadas em câmara de Neubauer.

Procedimento de Lavagem das Micro-esferas: As micro-esferas paramagnéticas encontradas no Kit foram completamente ressuspendidas e a quantidade desejada transferida para um tubo eppendorf de $1,5 \mathrm{~mL}$. O tubo foi colocado no concentrador de partículas magnético (Dynal MPC) por um minuto. Após este período o fluído límpido foi pipetado cuidadosamente para não movimentar as micro-esferas.

O tubo foi retirado do dispositivo magnético e as micro-esferas ressuspendidas em $1 \mathrm{~mL}$ de PBS/0,1\% BSA. O tubo foi novamente colocado no concentrador de partículas por $1 \mathrm{~min}$, o tampão foi removido, o tubo retirado e as micro-esferas lavadas ressuspendidas no volume original de tampão. 


\subsubsection{Separação negativa das células $B$ das células $M N C$}

Nesta etapa as células MNC foram incubadas com o mix de anticorpos e as micro-esferas de depleção adicionadas para remover as células indesejadas, ligadas aos anticorpos.

Para cada $10^{7}$ células MNC, utilizou-se $20 \mu \mathrm{L}$ do mix de anticorpos [B Cell Negative Isolation Kit (Dynal A.S, Oslo, Noruega)] e $100 \mu \mathrm{L}$ de micro-esferas de depleção conforme descrito abaixo.

As células, na concentração de $10^{7}$, foram ressuspendidas em $100 \mu \mathrm{L}$ de $\mathrm{PBS} / 0,1 \% \mathrm{BSA}$ e incubadas com $20 \mu \mathrm{L}$ do mix de anticorpos por $10 \mathrm{~min},-8^{\circ} \mathrm{C}$. Após este período, as células foram lavadas adicionando-se $1 \mathrm{~mL}$ de $\mathrm{PBS} / 0,1 \% \mathrm{BSA}$ e centrifugadas $8 \mathrm{~min}, 500 \mathrm{~g}$. O sobrenadante foi removido com pipeta Pasteur e as células ressuspendidas em $0,9 \mathrm{~mL}$ de $\mathrm{PBS} / 0,1 \%$ BSA e os $100 \mu \mathrm{L}$ das micro-esferas previamente lavadas foram adicionadas.

As células foram incubadas por $15 \mathrm{~min}$ em gelo, com rotação e inclinação suaves. Em seguida, as rosetas foram ressuspendidas por pipetagem (5-6 vezes) antes de ter seu volume aumentado pela adição de $1 \mathrm{~mL}$ de PBS/0,1\% BSA.

O tubo foi colocado por 2 min no Dynal MPC e o sobrenadante contendo as células $\mathrm{B}$ isoladas negativamente, transferido para um tubo novo. O mesmo foi centrifugado $8 \mathrm{~min}, 500 \mathrm{~g}, 4^{\circ} \mathrm{C}$ e o sobrenadante removido com pipeta Pasteur. $\mathrm{O}$ botão de células foi ressuspendido em $1 \mathrm{~mL}$ de TRIZOL $\AA$, agitado vigorosamente e mantido à temperatura de $-80^{\circ} \mathrm{C}$ até seu posterior processamento.

\subsubsection{Separação negativa das células $T$ das células $M N C$}

As células $\mathrm{T}$ foram isoladas a partir de células MNC inicialmente separadas, conforme metodologia anteriormente citada.

As micro-esferas foram lavadas e ressuspendidas de acordo com os procedimentos previamente mencionados. 
Nesta etapa as células MNC foram incubadas com mix de anticorpos e as micro-esferas de depleção adicionadas para remover as células indesejadas ligadas aos anticorpos.

Para cada $10^{7}$ células MNC, utilizou-se $20 \mu \mathrm{L}$ do mix de anticorpos [T Cell Negative Isolation Kit (Dynal A.S, Oslo, Noruega)] e $100 \mu \mathrm{L}$ de micro-esferas de depleção conforme descrito a seguir.

As células, na concentração de $10^{7}$, foram ressuspendidas em $100 \mu \mathrm{L}$ de $\mathrm{PBS} / 0,1 \%$ BSA e incubadas com $20 \mu \mathrm{L}$ do mix de anticorpos por $10 \mathrm{~min},-8^{\circ} \mathrm{C}$. Após este período, as células foram lavadas adicionando-se $1 \mathrm{~mL}$ de $\mathrm{PBS} / 0,1 \% \mathrm{BSA}$ e centrifugadas $8 \mathrm{~min}, 500 \mathrm{~g}$. O sobrenadante foi removido com pipeta Pasteur e as células ressuspendidas em $0,9 \mathrm{~mL}$ de $\mathrm{PBS} / 0,1 \% \mathrm{BSA}$ e os $100 \mu \mathrm{L}$ das micro-esferas previamente lavadas foram adicionadas.

As células foram incubadas por 15 min em gelo com rotação e inclinação suaves. Em seguida, as rosetas foram cuidadosamente ressuspendidas por pipetagem (5-6 vezes) antes de ter seu volume aumentado pela adição de $1 \mathrm{~mL}$ de PBS/0,1\% BSA.

O tubo foi colocado por 2 min no Dynal MPC e o sobrenadante contendo as células $\mathrm{T}$ isoladas negativamente, foi transferido para um novo tubo. $\mathrm{O}$ mesmo foi centrifugado $8 \mathrm{~min}, 500 \mathrm{~g}, 4^{\circ} \mathrm{C}$ e o sobrenadante removido com pipeta Pasteur. $\mathrm{O}$ botão de células foi ressuspendido em $1 \mathrm{~mL}$ de TRIZOL $\AA$, agitado vigorosamente e mantido à temperatura de- $80^{\circ} \mathrm{C}$ até seu posterior processamento.

\subsubsection{Expressão Gênica}

\subsubsection{Extração do RNA Celular}

$\mathrm{O}$ mRNA dos linfócitos $\mathrm{T}$ e $\mathrm{B}$ que se encontravam congelados a $-80^{\circ} \mathrm{C}$, foi extraído de cada tipo celular segundo protocolo do Kit (Micro Poly(A) pure, Ambion, E.U.A.). Resumidamente, as células T e B foram lisadas em tampão desnaturante e a cauda poli (A) presente no mRNA ligada a uma resina de celulose e oligo(dT), em um tampão com alta concentração salina. Posteriormente, o mRNA foi eluído da amostra e 
precipitado em $550 \mu \mathrm{l}$ de etanol 100\% gelado, $20 \mu \mathrm{l}$ de acetato de amônia $5 \mathrm{M}$ e $1 \mu 1$ de glicogênio. A amostra foi deixada em congelador a $-20^{\circ} \mathrm{C}$ por 12 horas e depois centrifugada a $12000 \mathrm{~g}$ por $20 \mathrm{~min}$ a $4^{\circ} \mathrm{C}$. O pellet de mRNA foi ressuspendido em $10,0 \mu \mathrm{L}$ de $\mathrm{H}_{2} \mathrm{O}$ miliQ tratada com DEPC.

3.3.2.2. Determinação semi-quantitativa da expressão do mRNA do gene do IGF-IR

A expressão do mRNA foi avaliada pela técnica de RT-PCR semi-quantitativa (semi-quantitative reverse transcriptase-polymerase chain reaction), na qual a transcrição reversa do RNA depende de uma primeira reação com a enzima transcriptase reversa (RT: reverse transcriptase) e, posteriormente, da amplificação com iniciadores específicos para cada região de interesse por reação de polimerase em cadeia (PCR: polymerase chain reaction).

\subsubsection{Sintese do DNA Complementar (cDNA)}

Dez microlitros de mRNA, extraído de acordo com a técnica descrita anteriormente, foram utilizados na síntese de cDNA por ação da transcriptase reversa (Superscript II/Rnase II reverse transcriptase, Gibco-BRL Life technologie. Gaithersburg, E.U.A.). Resumidamente, o volume total de $20 \mu \mathrm{L}$ compreendeu os seguintes reagentes: 10 microlitros de mRNA, 100 pmoles de hexanucleotídeos randômicos, 5x tampão da enzima, 0,1 M de ditiotreitol, $500 \mathrm{mM}$ de cada um dos desoxinucleosídeos, 200 unidades de SuperScript II. A reação foi processada a $42^{\circ} \mathrm{C}$ por $50 \mathrm{~min}$ e a $70^{\circ} \mathrm{C}$ por $15 \mathrm{~min}$ no termociclador Mastercycle ${ }^{\circledR}$ Gradient (Eppendorf AG., Hamburg, Alemanha).

\subsubsection{Curva de Aferição da RT-PCR}

As curvas de aferição dos RT-PCR foram obtidas por co-amplificação do gene BCR com o gene em estudo. Respeitando a fase exponencial da curva de amplificação da PCR, o número ideal de ciclos para os linfócitos T e B foi de 40 para o IGF-IR. Para determinarmos a temperatura de "annealing" ideal para a co-amplificação do gene do 
IGF-IR com o BCR, realizamos o gradiente de temperatura. Para este experimento utilizamos cDNA obtido de leucócitos. A reação de PCR foi realizada no Mastercycler ${ }^{\circledR}$ Gradient (Eppenforf AG. Hamburg, Alemanha) em diferentes temperaturas de "annealing". A temperatura ideal foi de $57^{\circ} \mathrm{C}$ para o gene em estudo, para os linfócitos T e B.

\subsubsection{Amplificação pela PCR utilizando-se controle interno: Linfócitos Te $B$}

A reação para amplificação do gene de interesse foi realizada de acordo com o seguinte protocolo: $2,0 \mu \mathrm{L}$ de cDNA, $0,42 \mathrm{mM}$ de cada um dos amplímeros do gene do IGF-IR e 0,21 mM para o controle interno (BCR), $220 \mathrm{mM}$ de cada um dos desoxinucleotídeos (dATP, dCTP, dGTP, dTTP), tampão termofílico 1 X (50 mM $\mathrm{KCl}, 1,5 \mathrm{mM} \mathrm{MgCl}$, $20 \mathrm{mM}$ TRIS-HCL) e $2 \mathrm{U}$ de Taq DNA polimerase (Pharmacia, Upsalla, Suécia).

O protocolo de amplificação utilizado foi realizado em termociclador (MJ Research INC-Perkin Elmer Cetus. Emeryville, EUA) e foi constituído de um ciclo de desnaturação inicial a $94^{\circ} \mathrm{C}, 2 \min$ e 35 ciclos de temperatura: $94^{\circ} \mathrm{C}$ por $30 \mathrm{~s}$ (desnaturação), $57^{\circ} \mathrm{C}$ por $30 \mathrm{~s} \mathrm{(“annealing”)} \mathrm{e} 68^{\circ} \mathrm{C}$ por 2 min (extensão). Após os ciclos de amplificação as amostras foram incubadas a $72^{\circ} \mathrm{C}$ por 2 min (alongamento). $\mathrm{O}$ produto da reação foi mantido a $4^{\circ} \mathrm{C}$ até sua análise por eletroforese em gel de agarose $2 \%$ corado com brometo de etídeo $0,5 \%$ em tampão TAE $1 \mathrm{x}$.

Sete microlitros do produto de cada reação foram submetidos à eletroforese em gel de agarose $2 \%$ a $100 \mathrm{~V}$, por aproximadamente $45 \mathrm{~min}$ e, as bandas foram visualizadas pela luz ultravioleta (GelDoc 1000 Video Gel Documentation System, BioRad Laboratories. Hercules, EUA).

A expressão do gene para o IGF-IR, utilizando o gene BCR como controle interno endógeno, foi avaliada pelo método descrito acima com o uso dos seguintes amplímeros: 
IGF-IR:

Sense: 5'-ACC CGG AGT ACT TCA GCG CT-3'

Antisense: 5'-CAC AGA AGC TTC GTT GAG AA-3'

BCR:

Sense: 5'-GAG AAG AGG GCG AAC AAG-3'

Antisense: 5'-CTC TGC TTA AAT CCA GTG GC-3'

O produto final da reação apresentou um fragmento de $230 \mathrm{pb}$ dos exons $15 \mathrm{e}$ 16 do gene do IGF-IR. Para ambas reações, o comprimento do fragmento dos exons 11 a 14 do gene do controle interno BCR foi de $377 \mathrm{pb}$.

A densidade das bandas correspondentes aos produtos de amplificação dos cDNA dos genes de interesse foram quantificadas por densitometria ótica (Personal Densitometer SI, Molecular Dynamics. Sunnyvale. EUA) e os valores expressos em unidades arbitrárias de densidade ótica (U.A.D.O.).

3.3.3. Determinação das concentrações plasmáticas de GH, IGF-I total, IGFBP-3 e IGFBP-2

\subsubsection{Dosagem de GH}

A dosagem foi realizada por método de Imunofluorimetria a tempo resolvido DELPHIA (Perkin Elmer Life Science, Turku, Finlândia). Os coeficientes de variação intra e inter-ensaio foram de 3,9 e 3,7\%, respectivamente. A dose mínima detectável foi de $0,01 \mathrm{ng} / \mathrm{mL}$ e a dose efetiva de 50\% (ED50) para o ensaio de 1,47 ng/mL. Os valores de referência na criança encontram-se abaixo de $8,8 \mathrm{ng} / \mathrm{mL}$.

\subsubsection{Dosagem de IGF-I total}

O procedimento inclui inicialmente uma fase de extração onde o IGF-I é separado de suas proteínas de ligação (IGFBPs). A dosagem foi realizada pelo ensaio imuno-radiométrico (IRMA) não competitivo (Diagnostic Systems Laboratories Inc, 
Webster, E.U.A). O coeficiente de variação intra-ensaio foi de 3,4\% e o coeficiente de variação inter-ensaio foi de $8,2 \%$. O resultado foi expresso em $\mathrm{ng} / \mathrm{mL}$, a dose mínima detectável foi de $0,80 \mathrm{ng} / \mathrm{mL}$ e a ED50 para o ensaio de $231 \mathrm{ng} / \mathrm{mL}$.

A concentração de IGF-I no sangue varia sensivelmente com a idade. Durante a vida fetal e no recém nascido, os níveis de plasmáticos do IGF-I são baixos, atingindo um pico durante a puberdade e declinando gradualmente na vida adulta. Os valores de referência para o método variam de $20-528 \mathrm{ng} / \mathrm{mL}$ (crianças 0-3 anos), 29-576 ng/mL (crianças 4-6 anos), 53-1080 ng/mL (crianças 7-10 anos) e 68-1332 ng/mL (crianças 11-13 anos).

\subsubsection{Dosagem de IGFBP-3}

Utilizamos para dosagens da IGFBP-3 um ensaio imuno-radiométrico (Diagnostic Systems Laboratories Inc, Webster, E.U. A). O coeficiente de variação intra-ensaio foi de 3,9\% e o coeficiente de variação inter-ensaio foi de $0,6 \%$. O resultado foi expresso em $\mu \mathrm{g} / \mathrm{mL}$, a dose mínima detectável foi de $0,5 \mu \mathrm{g} / \mathrm{mL}$ e a ED50 para o ensaio de $5,68 \mu \mathrm{g} / \mathrm{mL}$. Os valores de referência para o método variam de 0,90 3,28 $\mu \mathrm{g} / \mathrm{mL}$ (crianças 0-5 anos ), 0,77-4,45 $\mu \mathrm{g} / \mathrm{mL}$ (crianças 6-9 anos) e 1,22-6,49 $\mu \mathrm{g} / \mathrm{mL}$ (crianças 10-13 anos).

\subsubsection{Normalização dos dados (Índice Z)}

Os dados obtidos pela determinação quantitativa do IGF-I total e IGFBP-3 foram normalizados em relação à idade baseando-se na média $(\mathrm{M})$ e desvio padrão (DP) encontrados em uma população de indivíduos normais classificados de acordo com a faixa etária (BRACCO, 1997) como exemplificado abaixo:

$$
\mathbf{Z}(\mathbf{H})=([\mathbf{H}]-\mathbf{M}) / \mathbf{D P}
$$

[H]: Concentrações de IGF-I total ou IGFBP-3 obtidas pelos métodos descritos acima. 


\subsubsection{Dosagem de IGFBP-2}

A IGFBP-2 foi quantificada por ensaio imuno-radiométrico não competitivo (Diagnostic Systems Laboratories Inc, Webster, E.U.A). O coeficiente de variação intra-ensaio foi de $8,5 \%$ e o coeficiente de variação inter-ensaio foi de 7,4\%. O resultado foi expresso em $\mathrm{ng} / \mathrm{mL}$, a dose mínima detectável foi de $0,50 \mathrm{ng} / \mathrm{mL}$ e a ED50 para o ensaio de 20,56 ng/mL. Os valores de referência para o método variam de 254-1920 ng/mL (crianças 0-5 anos), 224-1045 ng/mL (crianças 6-8 anos), 192-907 $\mathrm{ng} / \mathrm{mL}$ (crianças 9-11 anos) e 80-795 ng/mL (crianças 12-14 anos).

\subsubsection{Determinação das concentrações plasmáticas de Frutosaminas e Peptídeo C}

\subsubsection{Dosagem de Frutosaminas}

A dosagem de frutosaminas foi realizada pela técnica de Imunoturbidimetria (Roche, Alemanha). O coeficiente de variação intra-ensaio foi de $0,9 \%$ e o coeficiente de variação inter-ensaio foi de $2,9 \%$. O resultado foi expresso em micromol/L, a dose mínima detectável foi de 10,00 micromol/L. Os valores de referência para este método encontram-se abaixo de 285 micromol/L.

\subsubsection{Dosagem de Peptídeo C}

A dosagem de peptídeo $\mathrm{C}$ foi realizada pela técnica de Radioimunoensaio (Diagnostic Systems Laboratories Inc, Webster, E.U.A) em sistema automático de duplo canal. O coeficiente de variação intra-ensaio foi de $4,3 \%$ e o coeficiente de variação inter-ensaio foi de $4,0 \%$. O resultado foi expresso em $\mathrm{ng} / \mathrm{mL}$, a dose mínima detectável foi de $0,01 \mathrm{ng} / \mathrm{mL}$ e a ED50 para o ensaio de 2,27 ng/mL. Os valores de referência para este método encontram-se entre 1,0 e 3,5 ng/mL. 
3.3.5. Determinação das concentrações plasmáticas de anticorpos anti-ilhota de Langerhans citoplasmático (ICA), anticorpos anti-tirosina fosfatase (antiIA2) e anticorpos anti-descarboxilase do ácido glutâmico (anti-GAD)

\subsubsection{Anticorpo anti-ilhota de Langerhans citoplasmático (ICA)}

Utilizou-se para a dosagem deste anticorpo, a técnica de Enzimaimunoensaio (Biomerica, E.U. A) pelo teste qualitativo com "cut-off" definido.

\subsubsection{Anticorpo anti-tirosina fosfatase (anti-IA2)}

A dosagem deste anticorpo foi realizada pela técnica de Radioimunoensaio (R.S.R, Limited, Escócia) em sistema automático de duplo canal. O coeficiente de variação intra-ensaio foi de 4,3\% e o coeficiente de variação inter-ensaio foi de 3,4\%. O resultado foi expresso em $\mathrm{U} / \mathrm{mL}$, a dose mínima detectável foi de $0,1 \mathrm{U} / \mathrm{mL}$ e a ED50 para o ensaio de $38,50 \mathrm{U} / \mathrm{mL}$. Os valores considerados positivos para este método encontram-se acima de 1,0 U/mL (média $\pm 1 \mathrm{SD})$.

\subsubsection{Anticorpos anti-descarboxilase do ácido glutâmico (Anti-GAD)}

A dosagem foi realizada por método de Imunofluorimetria a tempo resolvido DELPHIA (Perkin Elmer Life Science, Turku, Finlândia). Os coeficientes de variação intra e inter-ensaio foram de $12,0 \%$ e 13,7\%, respectivamente. A dose mínima detectável foi de 3,0 ng/mL (média $\pm 2 \mathrm{SD}$ ) e a ED50 para o ensaio de 121,90 $\mathrm{ng} / \mathrm{mL}$. Os valores considerados positivos para este método encontram-se acima de $12,8 \mathrm{ng} / \mathrm{mL}$.

\subsection{Análise Estatística}

A análise estatística dos dados clínico-antropométricos, dosagens bioquímicas e os resultados obtidos por RT-PCR dos três diferentes grupos de pacientes, foi realizada pelo cálculo da mediana e desvio semi-quartílico utilizando-se a prova de KruskalWallis como método não-paramétrico para comparações entre os três grupos. 
Nas variáveis onde se observou diferença estatisticamente significativa entre os três grupos, a análise foi complementada com a prova de comparações múltiplas de Mann-Whitney entre grupos 2 x 2 e aplicada a correção de Bonferroni com nível de significância $(\alpha)$ de $0,0166(\alpha / 3=0,05 / 3=0,0166)$. Nas comparações 2 x 2 somente foram, portanto, considerados estatisticamente significantes os valores de $\mathrm{p}$ inferiores a 0,0166 .

$\mathrm{Na}$ análise de correlação entre os níveis plasmáticos dos componentes do sistema GH-IGF-IGFBPs, dados clínico-antropométricos, dosagens de frutosaminas, peptídeo C e a expressão do receptor nos diferentes grupos estudados, utilizou-se o teste de correlação de Pearson. Fixou-se em 0,05 ou 5\% o nível de rejeição da hipótese de nulidade. Os resultados foram expressos em Mediana $(\mathrm{Md}) \pm$ Desvio SemiQuartílico (Q). 


\section{RESULTADOS}

Os resultados individuais dos dados clínico-antropométricos, determinação das concentrações plasmáticas de componentes do sistema GH-IGF-IGFBP, frutosaminas, peptídeo C e positividade dos anticorpos, assim como as tabelas de correlação intervariáveis, estão apresentados nos anexos.

\subsection{Dados Clínico-Antropométricos}

Os resultados demonstrados na Tabela 1 em relação à idade, peso e altura foram estatisticamente diferentes quando comparados os três grupos.

Tabela 1: Dados clínico-antropométricos dos grupos analisados

\begin{tabular}{lcccc}
\hline & Grupo A & Grupo B & Grupo C & p \\
\hline Idade (anos) & $5,50 \pm 2,45$ & $8,37 \pm 1,06$ & $9,00 \pm 1,16$ & $\mathrm{p}<0,05$ \\
Peso (kg) & $18,70 \pm 5,25$ & $24,60 \pm 4,40$ & $30,10 \pm 4,23$ & $\mathrm{p}<0,05$ \\
Altura (cm) & $111,00 \pm 16,50$ & $126,25 \pm 6,75$ & $132,00 \pm 6,69$ & $\mathrm{p}<0,05$ \\
Tempo Diagn. (meses) & $3,00 \pm 2,12$ & $56,00 \pm 40,25$ & ------ & ------ \\
\hline
\end{tabular}

* prova aplicada: Kruskal-Wallis 
Os resultados demonstrados na Tabela 2 demonstram diferenças estatisticamente significantes em relação as variáveis idades, peso e altura quando comparamos o Grupo A em relação aos demais grupos.

Tabela 2: Dados clínico-antropométricos (Comparação 2 X 2)

\begin{tabular}{lcccc}
\hline & $\begin{array}{c}\text { Grupo A } \\
\mathbf{x} \\
\text { Grupo B }\end{array}$ & $\begin{array}{c}\text { Grupo A } \\
\mathbf{x} \\
\text { Grupo C }\end{array}$ & $\begin{array}{c}\text { Grupo B } \\
\mathbf{x} \\
\text { Grupo C }\end{array}$ & Resultados \\
\hline Idade & $\mathrm{p}$ & $\mathrm{p}$ & $\mathrm{p}$ & \\
Peso & $0,003^{*}$ & $0,008^{*}$ & 0,916 & $\mathrm{~A} \neq(\mathrm{B}=\mathrm{C})$ \\
Altura & $0,013^{*}$ & $0,003^{*}$ & 0,280 & $\mathrm{~A} \neq(\mathrm{B}=\mathrm{C})$ \\
\hline
\end{tabular}

* prova aplicada: Mann-Whitney

\subsection{Determinação das concentrações plasmáticas de Frutosaminas e Peptídeo C}

Os resultados demonstrados na Tabela 3 em relação as frutosaminas e peptídeo C foram estatisticamente significantes quando comparados os três grupos. Todos os indivíduos do grupo $\mathrm{C}$ apresentaram valores de frutosaminas e peptídeo $\mathrm{C}$ dentro dos valores de referência para o método.

Tabela 3: Frutosaminas e Peptídeo C dos grupos analisados

\begin{tabular}{lcccc}
\hline & Grupo A & Grupo B & Grupo C & p \\
\hline Frutosaminas $(\mu \mathrm{mol} / \mathrm{L})$ & $365,90 \pm 62,05$ & $444,25 \pm 68,27$ & $239,40 \pm 24,57$ & $\mathrm{p}<0,05$ \\
Peptídeo C $(\mathrm{ng} / \mathrm{mL})$ & $0,70 \pm 0,60$ & $0,75 \pm 0,46$ & $2,25 \pm 0,98$ & $\mathrm{p}<0,05$ \\
\hline
\end{tabular}

* prova aplicada: Kruskal-Wallis 
Os resultados demonstrados na Tabela 4 demonstram diferenças estatisticamente significantes em relação as variáveis frutosaminas e peptídeo $\mathrm{C}$ quando comparamos o grupo $\mathrm{C}$ em relação aos demais grupos.

Tabela 4: Frutosaminas e Peptídeo C (Comparação 2 X 2)

\begin{tabular}{lcccc}
\hline & $\begin{array}{c}\text { Grupo A } \\
\mathbf{x} \\
\text { Grupo B }\end{array}$ & $\begin{array}{c}\text { Grupo A } \\
\mathbf{x} \\
\text { Grupo C }\end{array}$ & $\begin{array}{c}\text { Grupo B } \\
\mathbf{x} \\
\text { Grupo C }\end{array}$ & Resultados \\
\hline Frutosaminas & 0,033 & $\mathrm{P}$ & $\mathrm{p}$ & \\
Peptídeo C & 0,737 & $0,001^{*}$ & $<0,0001^{*}$ & $(\mathrm{~A}=\mathrm{B}) \neq \mathrm{C}$ \\
\hline
\end{tabular}

* prova aplicada: Mann-Whitney

Observou-se correlação positiva estatisticamente significativa entre os valores de frutosaminas com as variáveis idades $(r=0,545 ; \mathrm{p}=0,029)$ e peso $(\mathrm{r}=0,630 ; \mathrm{p}=0,009)$ nos indivíduos do grupo B.

Foi observada, também, uma correlação negativa estatisticamente significativa $(r=-0,538 ; p=0,032)$ entre os valores de frutosaminas e peptídeo $\mathrm{C}$ nos indivíduos do grupo B.

Observou-se, também, uma correlação positiva estatisticamente significativa entre os valores de peptídeo C e IGFBP-2 no grupo A ( $r=0,795 ; \mathrm{p}=0,033)$. 


\subsection{Determinação das concentrações plasmáticas de GH, IGF-I total, Z(IGF-I), IGFBP-3, Z(IGFBP-3) e IGFBP-2}

Os resultados mostrados na Tabela 5 referentes às dosagens de componentes do sistema GH-IGF-IGFBP nos grupos estudados, mostraram diferença estatisticamente significativa entre os três grupos em relação à Z(IGFBP-3). As demais variáveis analisadas não mostraram diferenças entre os grupos estudados.

Tabela 5: GH, IGF-I total, Z(IGF-I), IGFBP-3, Z(IGFBP-3) e IGFBP-2 dos grupos analisados

\begin{tabular}{lcccc}
\hline & Grupo A & Grupo B & Grupo C & p \\
\hline GH $(\mathrm{ng} / \mathrm{mL})$ & $0,26 \pm 0,28$ & $0,22 \pm 1,07$ & $1,70 \pm 2,10$ & $\mathrm{~ns}$ \\
IGF-I total $(\mathrm{ng} / \mathrm{mL})$ & $252,00 \pm 224,40$ & $349,20 \pm 110,10$ & $457,20 \pm 229,80$ & $\mathrm{~ns}$ \\
Z(IGF-I) & $0,72 \pm 2,04$ & $0,99 \pm 1,44$ & $1,36 \pm 1,72$ & $\mathrm{~ns}$ \\
IGFBP-3 $(\mu \mathrm{g} / \mathrm{mL})$ & $3,95 \pm 0,82$ & $4,63 \pm 0,58$ & $4,88 \pm 0,57$ & $\mathrm{~ns}$ \\
Z(IGFBP-3) & $3,51 \pm 3,41$ & $1,87 \pm 0,89$ & $1,40 \pm 0,66$ & $\mathrm{p}<0,05$ \\
IGFBP-2 $(\mathrm{ng} / \mathrm{mL})$ & $528,41 \pm 157,15$ & $493,95 \pm 192,67$ & $516,24 \pm 144,02$ & $\mathrm{~ns}$ \\
\hline
\end{tabular}

* prova aplicada: Kruskal-Wallis

Os resultados da Tabela 6 mostram que ao utilizarmos a prova de MannWhitney para comparação $2 \times 2$ entre os grupos, não se observou, entretanto, diferença estatisticamente significativa para a variável Z(IGFBP-3).

Tabela 6: Z(IGFBP-3) (Comparação 2 X 2)

\begin{tabular}{|c|c|c|c|}
\hline & $\begin{array}{c}\text { Grupo A } \\
\text { x } \\
\text { Grupo B } \\
\end{array}$ & $\begin{array}{c}\text { Grupo A } \\
\text { x } \\
\text { Grupo C } \\
\end{array}$ & $\begin{array}{c}\text { Grupo B } \\
\text { x } \\
\text { Grupo C } \\
\end{array}$ \\
\hline & $\mathrm{p}$ & $\mathrm{p}$ & $\mathrm{p}$ \\
\hline Z(IGFBP-3) & 0,027 & 0,019 & 0,712 \\
\hline
\end{tabular}

* prova aplicada: Mann-Whitney 
Foram observadas correlações positivas estatisticamente significativas entre os valores de IGF-I e IGFBP-3 nos grupos $B(r=0,653 ; p=0,006)$ e $C(r=0,837 ; p=0,003)$ (Gráfico 1).

Gráfico 1: Correlações IGF-I total x IGFBP-3 (grupos B e C)

\section{IGF- I total x IGFBP-3}

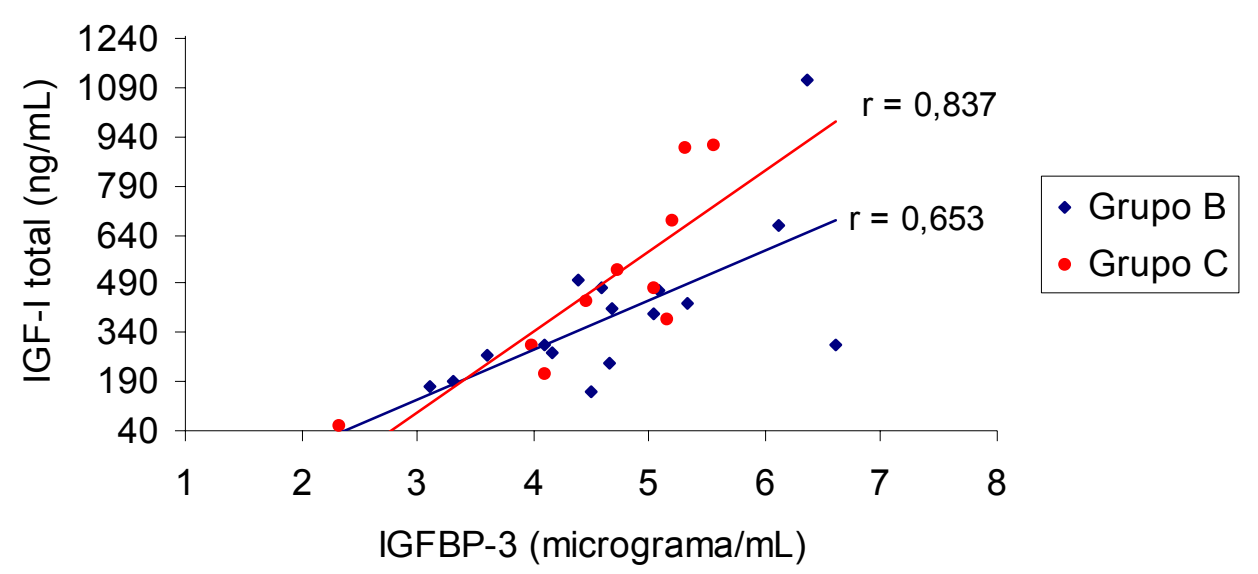

Observaram-se ainda correlações positivas estatisticamente significativas entre os valores de IGF-I e Z(IGFBP-3) $(r=0,864 ; p=0,012)$ e entre IGF-I e peptídeo C $(\mathrm{r}=0,766 ; \mathrm{p}=0,045)$ no grupo A. Os resultados do $\mathrm{Z}(\mathrm{IGF}-\mathrm{I})$ correlacionaram-se diretamente com os valores de Z(IGFBP-3) em dois grupos estudados: Grupo A $(r=0,977 ; p<0,0001)$ e Grupo B $(r=0,500 ; p=0,049)$.

Observou-se, também, correlação positiva estatisticamente significativa entre os valores de Z(IGF-I) e IGFBP-3 no grupo C ( $\mathrm{r}=0,701 ; \mathrm{p}=0,024)$. 


\subsection{Determinação da positividade de anticorpos anti-Ilhota de Langerhans citoplasmático (ICA), anticorpos anti-tirosina fosfatase (anti-IA2) e anticorpos anti-descarboxilase do ácido glutâmico (anti-GAD)}

A Tabela 7 apresenta o número total de pacientes com anticorpos positivos nos diferentes grupos analisados. Nenhum indivíduo estudado (grupo A, B ou C) apresentou positividade para os três anticorpos concomitantemente. Todos os indivíduos do grupo A apresentaram positividade para ao menos um dos anticorpos. No grupo A observou-se positividade de $2 / 7(28,5 \%)$ e 5/7 $(71,4 \%)$ para a presença de um e dois anticorpos respectivamente. No grupo B observou-se positividade de 9/16 $(56,2 \%)$ e 5/16 $(31,2 \%)$ respectivamente para a presença de um e dois anticorpos. Neste mesmo grupo, dois indivíduos não apresentarem positividade para nenhum dos anticorpos estudados (12,5\%). No grupo $\mathrm{C}$ observou-se $70 \%$ dos indivíduos sem positividade para qualquer anticorpo (7/10). A positividade para a presença de um anticorpo foi de $30 \%(3 / 10)$ e nenhum indivíduo apresentou positividade concomitante para mais de um anticorpo estudado.

Tabela 7: Número de pacientes com anticorpos positivos nos grupos analisados

\begin{tabular}{cccc}
\hline & $\mathbf{N}^{\mathbf{0}}$ pacientes & $\mathbf{N}^{\mathbf{0}}$ pacientes & $\mathbf{N}^{\mathbf{o}}$ pacientes \\
\hline $\begin{array}{c}\mathbf{N}^{\mathbf{0}} \text { anticorpos } \\
\text { positivos }\end{array}$ & Grupo A & Grupo B & Grupo C \\
\hline $\mathbf{0}$ & $0 / 7$ & $2 / 16$ & $7 / 10$ \\
$\mathbf{1}$ & $2 / 7$ & $9 / 16$ & $3 / 10$ \\
$\mathbf{2}$ & $5 / 7$ & $5 / 16$ & $0 / 10$ \\
$\mathbf{3}$ & $0 / 7$ & $0 / 16$ & $0 / 10$ \\
\hline
\end{tabular}


A Tabela 8 expressa a porcentagem de positividade dos diversos anticorpos nos grupos estudados. A positividade do ICA foi observada em $71,4 \%, 18,7 \%$ e $0 \%$ respectivamente para os grupos A, B e C (Gráfico 2).

Tabela 8: \% de positividade dos anticorpos nos grupos analisados

\begin{tabular}{lccc}
\hline & Grupo A & Grupo B & Grupo C \\
\hline ICA & $71,4 \%$ & $18,7 \%$ & $0 \%$ \\
Anti-IA2 & $42,8 \%$ & $31,2 \%$ & $0 \%$ \\
Anti-GAD & $57,1 \%$ & $68,7 \%$ & $30,0 \%$ \\
\hline
\end{tabular}

Gráfico 2: Determinação do ICA (grupos A, B e C)

\section{ICA}

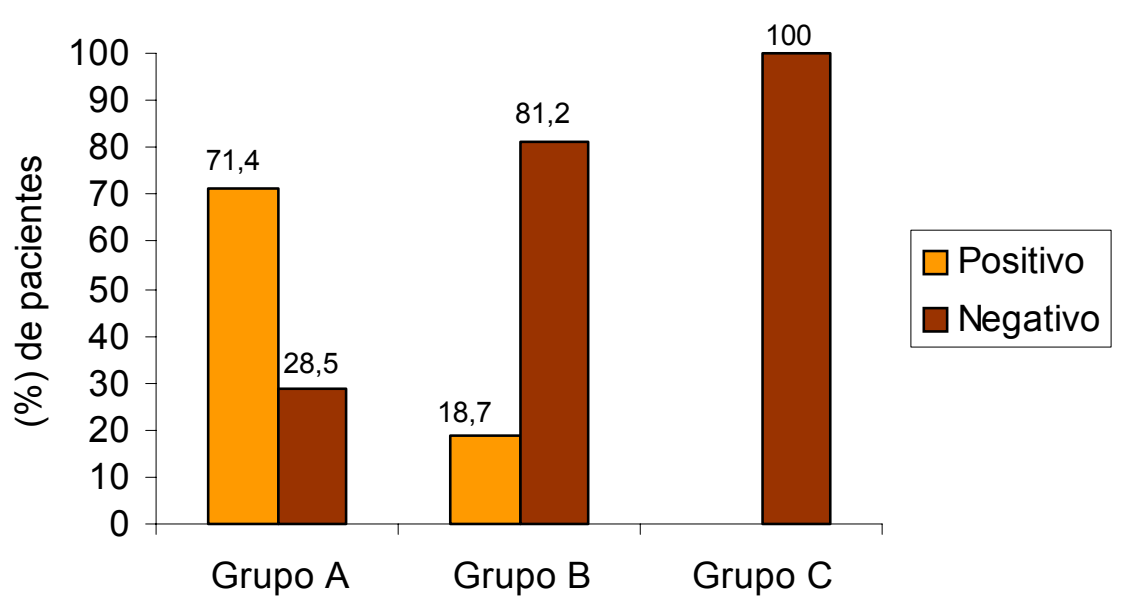


A positividade do anti-IA2 foi observada em 42,8\%, 31,2\% e $0 \%$ respectivamente para os grupos $\mathrm{A}, \mathrm{B}$ e C (Gráfico 3).

Gráfico 3: Determinação do anti-IA2 (grupos A, B e C)

\section{Anti-IA2}

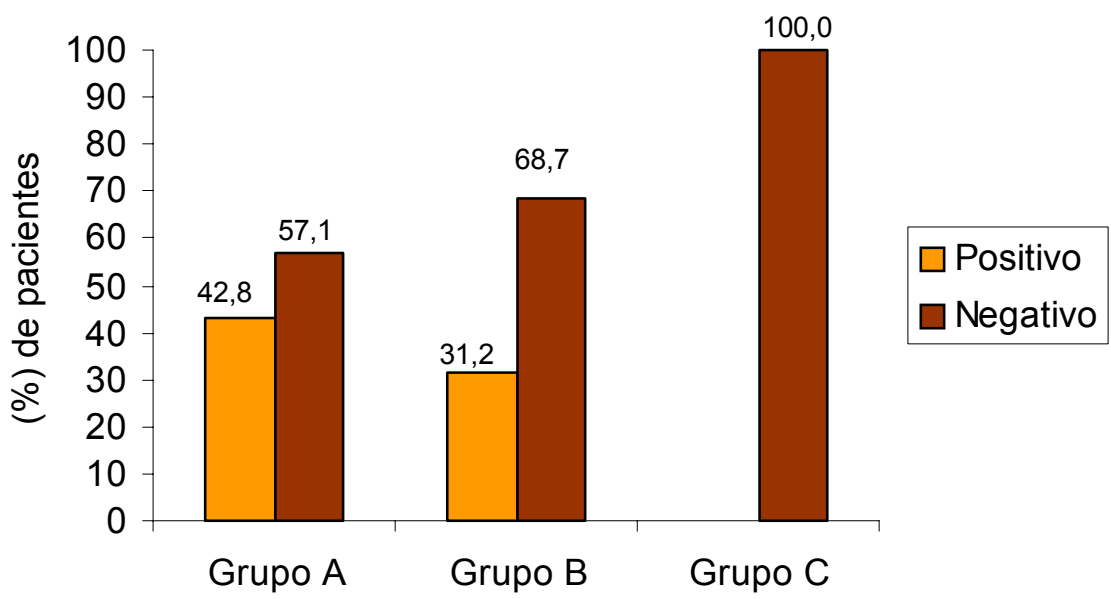

A positividade do anti-GAD foi observada em 57,1\%, 68,7\% e 30,0\% respectivamente para os grupos $\mathrm{A}, \mathrm{B}$ e C (Gráfico 4).

Gráfico 4: Determinação do anti-GAD (grupos A, B e C)

\section{Anti-GAD}

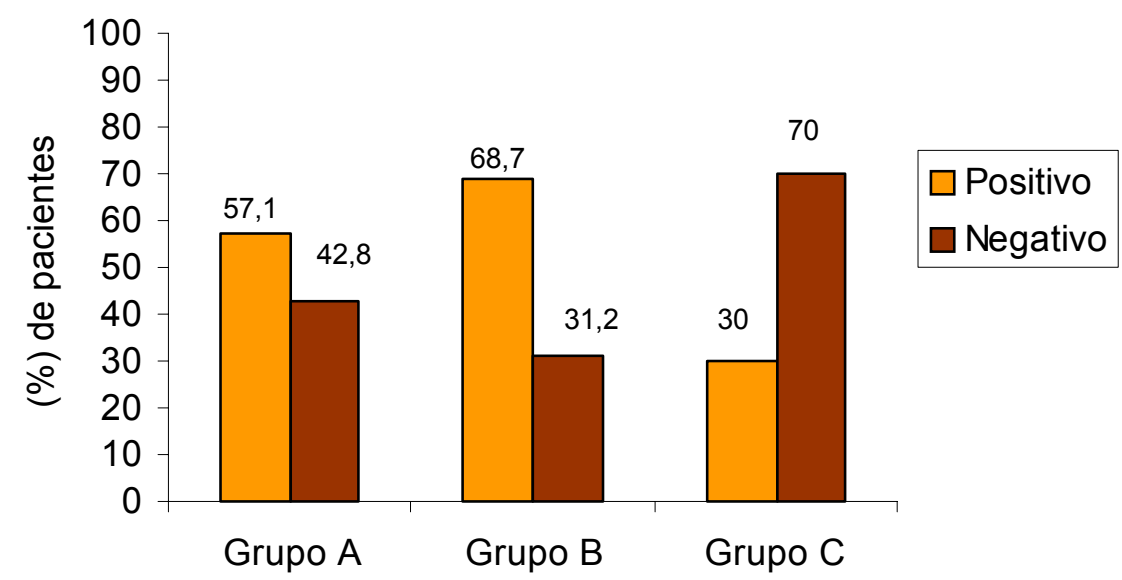




\subsection{Ensaio de RT-PCR para análise do mRNA do IGF-IR em Linfócitos T e B}

Os resultados demonstrados na Tabela 9 em relação à expressão do mRNA do IGF-IR nos linfócitos B foram estatisticamente significantes quando comparados os três grupos.

Tabela 9: Expressão do mRNA do IGF-IR dos grupos analisados

\begin{tabular}{lcccc}
\hline & Grupo A & Grupo B & Grupo C & p \\
\hline Linfócitos T (U.A.D.O.) & $0,73 \pm 0,03$ & $0,72 \pm 0,06$ & $0,72 \pm 0,11$ & $\mathrm{~ns}$ \\
& $(0,64-0,81)$ & $(0,56-1,00)$ & $(0,53-0,85)$ & \\
& & & & \\
Linfócitos B (U.A.D.O.) & $0.86 \pm 0.21$ & $0.65 \pm 0.08$ & $0.52 \pm 0.05$ & $\mathrm{p}<0,05$ \\
& $(0,58-1,20)$ & $(0,38-1,06)$ & $(0,43-0,64)$ & \\
\hline
\end{tabular}

* prova aplicada: Kruskal-Wallis

Os resultados da Tabela 10 e do Gráfico 5 demonstram diferenças estatisticamente significantes quando comparamos o grupo $\mathrm{C}$ com os demais grupos em relação à expressão do mRNA do IGF-IR nos linfócitos B.

Tabela 10: Expressão do mRNA do IGF-IR dos linfócitos B (Comparação 2 x 2)

\begin{tabular}{lcccc}
\hline & $\begin{array}{c}\text { Grupo A } \\
\mathbf{x} \\
\text { Grupo B }\end{array}$ & $\begin{array}{c}\text { Grupo A } \\
\mathbf{x}\end{array}$ & $\begin{array}{c}\text { Grupo B } \\
\mathbf{\text { Grupo C }}\end{array}$ & $\begin{array}{c}\text { Grupo C } \\
\text { Resultados }\end{array}$ \\
\hline Linfócitos B & $\mathrm{p}$ & $\mathrm{p}$ & $\mathrm{p}$ & \\
& 0,094 & $0,002^{*}$ & $0,006^{*}$ & $(\mathrm{~A}=\mathrm{B}) \neq \mathrm{C}$ \\
\hline
\end{tabular}

* prova aplicada: Mann-Whitney 
Gráfico 5: Expressão do mRNA do IGF-IR dos linfócitos B (comparação grupos A, B e C)

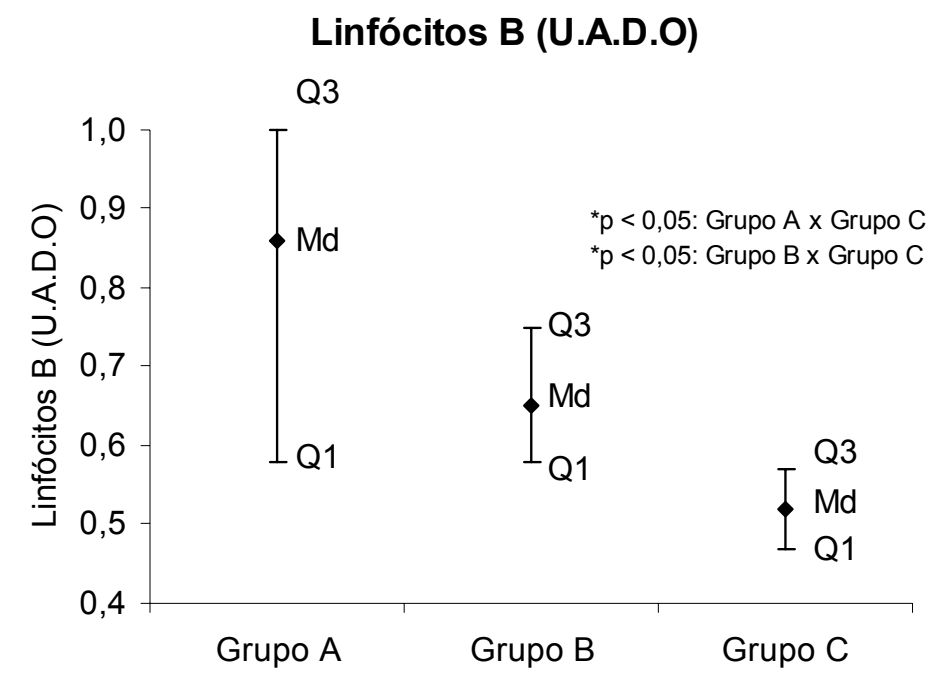

A expressão do mRNA do IGF-IR nos linfócitos B mostrou correlação positiva estatísticamente significativa no grupo A com os níveis de IGFBP-3 ( $\mathrm{r}=0,834$; $\mathrm{p}=0,020)$.

Em relação à expressão do mRNA do IGF-IR dos linfócitos T, não se observou diferença estatisticamente significativas entre os grupos (Gráfico 6).

Gráfico 6: Expressão do mRNA do IGF-IR dos linfócitos T (comparação

$$
\text { grupos A, B e C) }
$$

\section{Linfócitos T (U.A.D.O)}

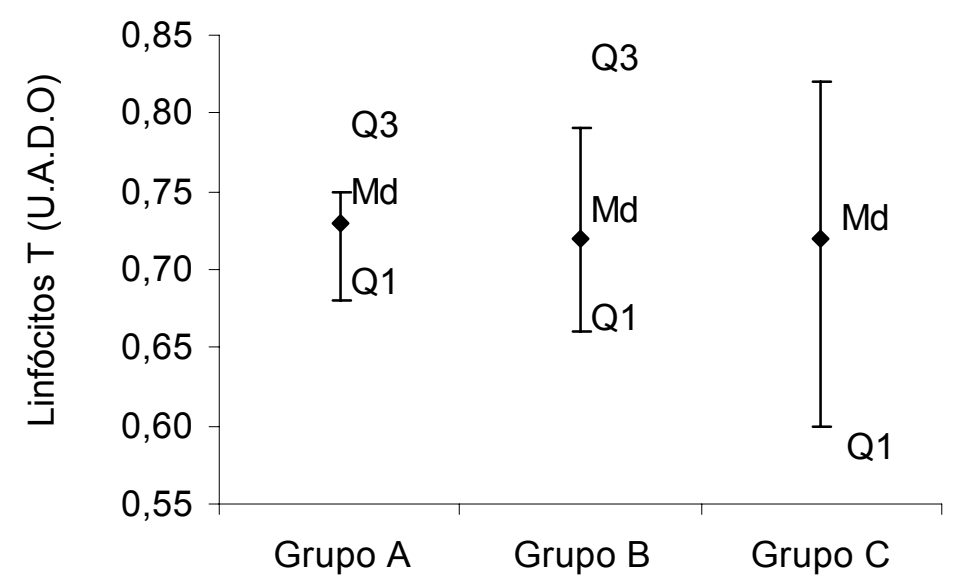


A expressão do mRNA do IGF-IR nos linfócitos $\mathrm{T}$ mostrou correlação estatisticamente significativa no grupo A com as variáveis idade $(r=0,776 ; p=0,040)$, peso $(r=0,761 ; p=0,047)$ e altura $(r=0,785 ; p=0,036)$. 


\section{DISCUSSÃO}

A inter-relação entre os sistemas endócrino e imune foi sugerida pela primeira vez na década de 30, após a observação da involução quase imediata do timo de ratos submetidos a ablação cirúrgica da hipófise anterior (SMITH, 1930). As evidências subseqüentes da atividade imunológica dos hormônios somatogênicos provêm de estudos realizados em ratos hipofisectomizados, que apresentaram uma queda importante dos níveis de hemoglobina, da contagem leucocitária e da produção de anticorpos quando comparados a animais controle (EVERITT \& CAVANAGH, 1965). A inibição ou, também, a estimulação de diversos sistemas hormonais pode afetar direta ou indiretamente a resposta imune. "In vivo", GH, PRL e hormônios tireoideanos parecem estimular a resposta imunológica enquanto ACTH, glicocorticóides, estrógenos, progesterona e andrógenos promovem o inverso (CLARK, 1997).

O DM1 é uma doença crônica auto-imune, resultante da interação de fatores ambientais e genéticos que promovem uma destruição seletiva das células- $\beta$, através de um mecanismo imunológico mediado por células T (GALE, 2001; ATKINSON \& EISENBARTH, 2001). Muito embora a maioria dos pacientes apresentem autoimunidade humoral ao diagnóstico da dependência insulínica, a recente obeservação de que o DM1 pode ocorrer em pacientes com insuficiência absoluta de linfócitos B e auto-anticorpos (MARTIN et al., 2001 e ROEP et al., 2002) demonstra que a imunidade humoral poderia não estar envolvida no processo de iniciação da doença (BINGLEY et al., 1997; LENMARK et al., 1999 e LESLIE et al., 1999). O verdadeiro papel dos anticorpos na etiopatogenia da doença é ainda incerto. Os anticorpos poderiam ter participação direta nos mecanismos de lesão celular ou, mais 
provavelmente, seriam secundários a liberação de antígenos provenientes das ilhotas, através de outros mecanismos de destruição.

A etiologia auto-imune do DM1 é, também, sugerida pela presença de anticorpos circulantes, específicos para antígenos da célula- $\beta$, que incluem IAA, ICA, anti-GAD e anti-IA2. (GENOVESE et al., 1992 e KOLB et a., 1988). Estes anticorpos são detectáveis em $85-90 \%$ dos indivíduos na época do diagnóstico. A presença de 2 ou mais espécies diferentes de anticopos está associado a um maior risco dos parentes de $1^{\circ}$ grau de pacientes diabéticos de desenvolver a doença (BINGLEY et al, 1997; LENMARK et al, 1999 e LESLIE et al, 1999). Esta observação sugere que o número e os tipos dos anticorpos presentes pode distinguir a magnitude da atividade da doença (BINGLEY et al, 1997 e KULMALA et al, 1998). Embora alguns autores tenham mostrado que altos títulos de múltiplos anticorpos podem ser um sinal precoce de progressão rápida da doença associada à perda da função da célula $\beta$ residual durante os primeiros anos do acometimento (PETERSEN et al., 1994; MAURICIO et al., 1997; SEISSLER et al., 1998; SABBAH et al., 1999; DECOCHEZ et al., 2000 e BORG et al., 2001), esta observação não pode ser comprovada por outros autores (LUDVIGSSON et al., 1997 e TORN et al., 2001).

$\mathrm{Na}$ época do diagnóstico clínico, acredita-se que ocorra destruição de pelo menos $80 \%$ das células- $\beta$. Tem sido demonstrado em modelos experimentais que a resposta insulínica aguda à glicose torna-se, entretanto, indetectável mesmo quando ainda 40-50\% das células-ß encontram-se presentes (McCULLOCH et al., 1991).

Os IGFs são consideradas peptídeos mitogênicos e estão implicadas na regulação da proliferação celular. Nos últimos anos, diversos estudos têm sugerido um papel adicional do sistema GH-IGF-IGFBP nos mecanismos de apoptose e ativação imunológica. A via de sinalização através do IGF-IR mostrou ser um potente mecanismo de proteção celular frente a diversos estímulos apoptóticos. As ações dos IGFs são reguladas pelas IGFBPs, que modulam sua ação através da interação destas proteínas com o IGF-IR. Existem evidências, entretanto, que, especialmente, a IGFBP3 possui efeitos pró-apoptóticos independentes da sua capacidade de modular a disponibilidade dos IGFs (FIRTH \& BAXTER, 2002). 
O IGF-IR atuaria nos mecanismos de ativação imunológica e proliferação celular por sinais mitogênicos, proteção celular frente a estímulos apoptóticos, aumento do tamanho das células, estabelecimento e manutenção do fenótipo transformado e regulação da adesão e motilidade celular (VALENTINIS \& BASERGA, 2001).

Foi demonstrado que o IGF-I liga-se preferencialmente aos monócitos e linfócitos periféricos quando não ativados (STUART et al., 1991) e que o número de receptores para IGF-I apresentava-se relativamente alto em monócitos, células naturalkiller e linfócitos $\mathrm{T}$ helper CD4+, moderado em linfócitos $\mathrm{T}$ citotóxico CD8+ e baixo nos linfócitos B. Estes achados indicam que o efeito positivo do IGF-I sobre a citotoxicidade de linfócitos $\mathrm{T}$ natural-killer pode estar relacionado ao papel funcional do IGF-I nestas células (KOOIJMAN et al., 1992).

$\mathrm{Na}$ presente investigação, foram estudados e comparados 3 grupos de indivíduos (Grupo A: indivíduos portadores de DM1 com diagnóstico recente $-\leq 6$ meses; Grupo B: indivíduos portadores de DM1 com diagnóstico > 6 meses; Grupo C: indivíduos não diabéticos). Os dados clínico-antropométricos dos diferentes grupos mostraram diferenças estatísticas significantes nas variáveis idade, peso e altura entre os indivíduos diabéticos com diagnóstico recente quando comparados aos outros dois grupos, decorrentes provavelmente da menor faixa etária observada nos indivíduos com diagnóstico mais precoce.

Os resultados referentes as frutosaminas e a dosagem de Peptídeo C, não foram estatisticamente significantes quando comparados os indivíduos diabéticos entre si, sugerindo não haver diferenças tanto no controle glicêmico quanto na reserva de insulina destes indivíduos.

Foram, também, avaliadas e comparadas as proteínas do sistema GH-IGFIGFBP nos diferentes grupos estudados, não mostrando diferenças estatísticas significantes entre os três grupos.

Ao analisarmos isoladamente as proteínas do sistema GH-IGF-IGFBP, observa-se uma tendência de maiores valores de IGF-I total e IGFBP-3 nos indivíduos não-diabéticos, corroborando com dados prévios da literatura (BERKET et al., 1999). 
O estudo comparativo dos auto-anticorpos nos grupos avaliados mostrou semelhanças quando comparados aos trabalhos de prevalência encontrados na literatura. A determinação do ICA, através da técnica de Enzimaimunoensaio, mostrou maior prevalência $(71,4 \%)$ no grupo de indivíduos com diagnóstico mais precoce da doença, tendendo a desaparecer na maioria dos indivíduos diabéticos com a progressão da doença. Em nossa casuística, não observamos positividade deste anticorpo em nenhum indivíduo não diabético. A prevalência de positividade para o anti-IA2 foi de $42,8 \%$ nos indivíduos com diagnóstico precoce e 31,2\% em indivíduos com diagnóstico mais tardio. Similarmente observado com o ICA, a nossa casuística não demonstrou positividade do anti-IA2 nos indivíduos não diabéticos. Dados avaliando grande número de indivíduos diabéticos recém-diagnósticados, demonstram positividade de até $85 \%$ para o anti-IA2 nessa população (SABBAH et al., 1999). Observamos maior prevalência do anti-GAD no grupo com diagnóstico mais tardio $(68,7 \%)$ e alta prevalência (30\%) nos indivíduos não diabéticos. A enzima GAD não é exclusiva do tecido pancreático e pode ser, também, produzida em outros locais como testículos, ovários e células do sistema nervoso. É interessante notar, que os nossos dados não demonstraram positividade para os três anticorpos simultaneamente em nenhum indivíduo estudado.

Na presente investigação foi estudada a expressão do IGF-IR nos linfócitos T e $\mathrm{B}$ de indivíduos não diabéticos e indivíduos diabéticos em diferentes etapas do diagnóstico através da metodologia de RT-PCR. A comparação dos resultados obtidos no ensaio de RT-PCR entre os grupos analisados, não mostrou diferença estatisticamente significativa na expressão do mRNA do IGF-IR nos linfócitos T, sugerindo que a ativação imunológica destas células seja independente da ação do IGFIR. A expressão do mRNA do IGF-IR nos linfócitos B apresentou-se aumentada em indivíduos diabéticos com até 6 meses de diagnóstico e com tempo de diagnóstico superior a 6 meses, em relação aos indivíduos não diabéticos.

No grupo de indivíduos diabéticos com até 6 meses de diagnóstico, foi observada uma correlação estatisticamente significativa com níveis de IGFBP-3. Ao examinarmos este subgrupo de pacientes, observamos, também, forte positividade para o anticorpo ICA nos indivíduos com maior expressão do mRNA do IGF-IR nos 
linfócitos B, reforçando o papel deste receptor na ativação imunológica desta linhagem celular.

Estes resultados associados à observação do papel do IGF-IR nos mecanismos envolvidos na resposta imunológica, ações imunomoduladoras já conhecidas das IGFBPs (em especial a IGFBP-3) e presença de anticorpos específicos para antígenos liberados pelas células- $ß$ durante a sua destruição imunológica, sugerem fortemente o papel do IGF-IR nos mecanismos envolvidos na etiopatogenia do DM1.

Os defeitos na sinalização de sinais celulares desempenham papel relevante no desenvolvimento do diabetes e de suas complicações associadas. As células sangüíneas isoladas de portadores de diabetes tem sido empregadas nos estudos sobre as alterações fisiopatológicas de diversas vias de transdução de sinal. O emprego de linfócitos como paradigma celular apresenta algumas vantagens, particularmente, no diabetes melito: (a) são facilmente acessíveis; (b) apresentam as mesmas proteínas transportadoras presentes nas células musculares lisas vasculares, miocárdio e outras células-alvo afetadas pelo diabetes; (c) os linfoblastos imortalizados conservam o fenótipo característico das alterações iônicas demonstradas no linfócito isolado do pacientes diabético e (d) podem fornecer DNA genômico para o estudo dos mecanismos genéticos envolvidos nas complicações diabéticas. (BALASUBRAMANYAM et al., 2002).

$\mathrm{Na}$ presente investigação, consideramos, portanto, que a atividade clínica do DM1 diagnosticado recentemente pode ser conferida pela presença de auto-anticorpos cuja produção envolve um número maior de linfócitos $\mathrm{B}$ em atividade proliferativa dependente da presença dos receptores de IGF-I. 


\section{CONCLUSÕES}

Neste estudo, o receptor para o IGF-I foi encontrado em todas as populações linfocitárias analisadas. Em indivíduos não diabéticos foi observada uma maior expressão do mRNA do IGF-IR em linfócitos T em relação aos linfócitos B.

Não se observou diferenças entre as expressões do IGF-IR em linfócitos $\mathrm{T}$ de indivíduos diabéticos tipo 1 em fases diferentes de diagnóstico, bem como quando comparados indivíduos diabéticos tipo 1 e indivíduos não diabéticos.

Observou-se um aumento significativo da expressão do IGF-IR em linfócitos B de indivíduos diabéticos tipo 1 com até 6 meses de diagnóstico, bem como de indivíduos diabéticos tipo 1 com diagnóstico maior do que 6 meses, quando comparados a indivíduos não diabéticos, sugerindo uma possível participação do IGF-I e de seu receptor na proliferação e ativação destas células envolvidas na resposta imunológica do DM1.

Não se observou diferenças estatisticamente significantes entre a expressão do IGF-IR em linfócitos B de pacientes diabéticos tipo 1 com até 6 meses de diagnóstico e pacientes diabéticos tipo 1 com diagnóstico maior do que 6 meses.

A análise das determinações dos anticorpos (ICA, anti-IA2, anti-GAD) demonstrou maior prevalência do ICA e anti-IA2 nos indivíduos com diagnóstico mais precoce da doença, reforçando o papel destes anticorpos como marcadores de atividade imunológica.

Foi observada correlação positiva estatisticamente significativa entre a expressão do mRNA do IGF-IR em linfócitos B e níveis de IGFBP-3 em indivíduos 
diabéticos tipo 1 com até 6 meses de diagnóstico, suportando o papel deste elemento nos mecanismos envolvidos na resposta imunológica do DM1. 


\section{ANEXOS}

Tabela de Correlação - Idade

\begin{tabular}{lcccccc}
\hline & \multicolumn{2}{c}{ GRUPO A } & \multicolumn{2}{c}{ GRUPO B } & \multicolumn{2}{c}{ GRUPO C } \\
\hline & $\mathrm{r}=$ & $\mathrm{p}=$ & $\mathrm{r}=$ & $\mathrm{p}=$ & $\mathrm{r}=$ & $\mathrm{p}=$ \\
\hline Idade & ----- & ----- & ---- & ----- & ---- & ---- \\
Peso & 0,991 & $<0,0001^{*}$ & 0,956 & $<0,0001^{*}$ & 0,981 & $<0,0001^{*}$ \\
Altura & 0,998 & $<0,0001^{*}$ & 0,987 & $<0,0001^{*}$ & 0,995 & $<0,0001^{*}$ \\
Tdiag & 0,122 & 0,795 & 0,619 & $0,011^{*}$ & ----- & ----- \\
Linfócitos T & 0,776 & $0,040^{*}$ & 0,249 & 0,353 & 0,343 & 0,331 \\
Linfócitos B & 0,692 & 0,085 & 0,260 & 0,331 & $-0,060$ & 0,870 \\
GH & 0,444 & 0,319 & 0,077 & 0,776 & 0,016 & 0,964 \\
IGF-I & 0,227 & 0,624 & 0,116 & 0,670 & 0,533 & 0,113 \\
Z(IGF-I) & $-0,086$ & 0,854 & $-0,252$ & 0,346 & 0,307 & 0,388 \\
IGFBP-3 & 0,795 & $0,033^{*}$ & 0,416 & 0,109 & 0,858 & $0,001^{*}$ \\
Z(IGFBP-3) & $-0,105$ & 0,823 & $-0,820$ & $<0,0001^{*}$ & $-0,899$ & $<0,0001^{*}$ \\
IGFBP-2 & $-0,776$ & $0,040^{*}$ & $-0,180$ & 0,504 & $-0,538$ & 0,108 \\
FRTSM & 0,295 & 0,520 & 0,545 & $0,029^{*}$ & 0,536 & 0,110 \\
PEP C & $-0,348$ & 0,444 & $-0,124$ & 0,647 & 0,568 & 0,087 \\
\hline
\end{tabular}


Tabela de Correlação - Peso

\begin{tabular}{|c|c|c|c|c|c|c|}
\hline & \multicolumn{2}{|c|}{ GRUPO A } & \multicolumn{2}{|c|}{ GRUPO B } & \multicolumn{2}{|c|}{ GRUPO C } \\
\hline & $\mathrm{r}=$ & $\mathrm{p}=$ & $r=$ & $\mathrm{p}=$ & $\mathrm{r}=$ & $\mathrm{p}=$ \\
\hline Idade & 0,991 & $<0,0001^{*}$ & 0,956 & $<0,0001^{*}$ & 0,981 & $<0,0001^{*}$ \\
\hline Peso & ----- & ----- & ----- & ----- & ----- & ----- \\
\hline Altura & 0,983 & $<0,0001^{*}$ & 0,940 & $<0,0001^{*}$ & 0,971 & $<0,0001^{*}$ \\
\hline $\begin{array}{l}\text { Tempo } \\
\text { diagnóstico }\end{array}$ & 0,048 & 0,918 & 0,526 & $0,036^{*}$ & ----- & ----- \\
\hline Linfócitos T & 0,761 & $0,047^{*}$ & 0,187 & 0,488 & 0,349 & 0,323 \\
\hline Linfócitos B & 0,660 & 0,107 & 0,266 & 0,319 & $-0,019$ & 0,958 \\
\hline $\mathrm{GH}$ & 0,398 & 0,377 & $-0,049$ & 0,856 & 0,001 & 0,998 \\
\hline IGF-I & 0,157 & 0,736 & 0,057 & 0,834 & 0,531 & 0,114 \\
\hline Z(IGF-I) & $-0,145$ & 0,757 & $-0,328$ & 0,215 & 0,278 & 0,436 \\
\hline IGFBP-3 & 0,725 & 0,065 & 0,442 & 0,087 & 0,845 & $0,002 *$ \\
\hline Z(IGFBP-3) & $-0,175$ & 0,707 & $-0,775$ & $<0,0001 *$ & $-0,855$ & $0,002^{*}$ \\
\hline IGFBP-2 & $-0,787$ & $0,036^{*}$ & $-0,174$ & 0,519 & $-0,503$ & 0,138 \\
\hline FRTSM & 0,179 & 0,701 & 0,630 & $0,009 *$ & 0,497 & 0,144 \\
\hline PEP C & $-0,416$ & 0,353 & $-0,137$ & 0,613 & 0,513 & 0,129 \\
\hline
\end{tabular}


Tabela de Correlação - Altura

\begin{tabular}{lcccccc}
\hline & \multicolumn{2}{c}{ GRUPO A } & \multicolumn{2}{c}{ GRUPO B } & \multicolumn{2}{c}{ GRUPO C } \\
\hline & $\mathrm{r}=$ & $\mathrm{p}=$ & $\mathrm{r}=$ & $\mathrm{p}=$ & $\mathrm{r}=$ & $\mathrm{p}=$ \\
\hline Idade & 0,998 & $<0,0001^{*}$ & 0,987 & $<0,0001^{*}$ & 0,995 & $<0,0001^{*}$ \\
Peso & 0,983 & $<0,0001^{*}$ & 0,940 & $<0,0001^{*}$ & 0,971 & $<0,0001^{*}$ \\
Altura & ----- & ----- & ----- & ----- & ----- & ----- \\
Tempo & 0,116 & 0,804 & 0,608 & $0,013^{*}$ & ----- & ----- \\
diagnóstico & & & & & & \\
Linfócitos T & 0,785 & $0,036^{*}$ & 0,245 & 0,361 & 0,318 & 0,370 \\
Linfócitos B & 0,723 & 0,066 & 0,271 & 0,309 & $-0,072$ & 0,844 \\
GH & 0,453 & 0,308 & 0,034 & 0,901 & 0,070 & 0,847 \\
IGF-I & 0,293 & 0,523 & 0,078 & 0,773 & 0,499 & 0,142 \\
Z(IGF-I) & $-0,018$ & 0,969 & $-0,281$ & 0,292 & 0,299 & 0,433 \\
IGFBP-3 & 0,814 & $0,026^{*}$ & 0,323 & 0,222 & 0,853 & $0,002^{*}$ \\
Z(IGFBP-3) & $-0,038$ & 0,935 & $-0,872$ & $<0,0001^{*}$ & $-0,930$ & $<0,0001^{*}$ \\
IGFBP-2 & $-0,744$ & 0,055 & $-0,096$ & 0,723 & $-0,578$ & 0,080 \\
FRTSM & 0,336 & 0,461 & 0,488 & 0,055 & 0,527 & 0,117 \\
PEP C & $-0,289$ & 0,530 & $-0,116$ & 0,669 & 0,508 & 0,134 \\
\hline
\end{tabular}


Tabela de Correlação - Tempo diagnóstico

\begin{tabular}{lcccc}
\hline & \multicolumn{2}{c}{ GRUPO A } & \multicolumn{2}{c}{ GRUPO B } \\
\hline & $\mathrm{r}=$ & $\mathrm{p}=$ & $\mathrm{r}=$ & $\mathrm{p}=$ \\
\hline Idade & 0,122 & 0,795 & 0,619 & $0,011^{*}$ \\
Peso & 0,048 & 0,918 & 0,526 & $0,036^{*}$ \\
Altura & 0,116 & 0,804 & 0,608 & $0,013^{*}$ \\
Tempo diagnóstico & ----- & ---- & ---- & ---- \\
Linfócitos T & $-0,171$ & 0,714 & 0,185 & 0,493 \\
Linfócitos B & 0,122 & 0,794 & 0,036 & 0,896 \\
GH & 0,475 & 0,281 & 0,199 & 0,460 \\
IGF-I & $-0,041$ & 0,930 & $-0,194$ & 0,471 \\
Z(IGF-I) & $-0,259$ & 0,575 & $-0,409$ & 0,116 \\
IGFBP-3 & 0,365 & 0,420 & 0,048 & 0,860 \\
Z(IGFBP-3) & $-0,241$ & 0,603 & $-0,555$ & $0,026^{*}$ \\
IGFBP-2 & $-0,299$ & 0,515 & 0,181 & 0,501 \\
FRTSM & 0,449 & 0,312 & 0,388 & 0,137 \\
PEP C & 0,674 & 0,161 \\
\hline & & & & \\
\hline
\end{tabular}


Tabela de Correlação - Linfócitos T

\begin{tabular}{|c|c|c|c|c|c|c|}
\hline & \multicolumn{2}{|c|}{ GRUPO A } & \multicolumn{2}{|c|}{ GRUPO B } & \multicolumn{2}{|c|}{ GRUPOC } \\
\hline & $\mathrm{r}=$ & $\mathrm{p}=$ & $\mathrm{r}=$ & $\mathrm{p}=$ & $\mathrm{r}=$ & $\mathrm{p}=$ \\
\hline Idade & 0,776 & $0,040^{*}$ & 0,249 & 0,353 & 0,343 & 0,331 \\
\hline Peso & 0,761 & $0,047 *$ & 0,187 & 0,488 & 0,349 & 0,323 \\
\hline Altura & 0,785 & $0,036^{*}$ & 0,245 & 0,361 & 0,318 & 0,370 \\
\hline Tempo diagnóstico & $-0,171$ & 0,714 & 0,185 & 0,493 & ----- & ----- \\
\hline Linfócitos $\mathrm{T}$ & ----- & ----- & ----- & ----- & ----- & ----- \\
\hline Linfócitos B & 0,506 & 0,246 & 0,546 & $0,029 *$ & 0,553 & 0,097 \\
\hline $\mathrm{GH}$ & $-0,133$ & 0,776 & 0,028 & 0,919 & 0,102 & 0,780 \\
\hline IGF-I & 0,310 & 0,499 & 0,013 & 0,961 & 0,588 & 0,074 \\
\hline Z(IGF-I) & 0,187 & 0,687 & $-0,013$ & 0,961 & 0,511 & 0,131 \\
\hline IGFBP-3 & 0,628 & 0,131 & 0,124 & 0,647 & 0,385 & 0,272 \\
\hline Z(IGFBP-3) & 0,254 & 0,582 & $-0,108$ & 0,692 & $-0,338$ & 0,339 \\
\hline IGFBP-2 & $-0,553$ & 0,198 & 0,043 & 0,873 & 0,214 & 0,553 \\
\hline FRTSM & 0,215 & 0,643 & 0,277 & 0,299 & 0,695 & $0,026^{*}$ \\
\hline PEP C & $-0,141$ & 0,763 & $-0,271$ & 0,311 & 0,601 & 0,066 \\
\hline
\end{tabular}


Tabela de Correlação - Linfócitos B

\begin{tabular}{|c|c|c|c|c|c|c|}
\hline & \multicolumn{2}{|c|}{ GRUPO A } & \multicolumn{2}{|c|}{ GRUPO B } & \multicolumn{2}{|c|}{ GRUPO C } \\
\hline & $\mathrm{r}=$ & $\mathrm{p}=$ & $r=$ & $\mathrm{p}=$ & $\mathrm{r}=$ & $\mathrm{p}=$ \\
\hline Idade & 0,692 & 0,085 & 0,260 & 0,331 & $-0,060$ & 0,870 \\
\hline Peso & 0,660 & 0,107 & 0,266 & 0,319 & $-0,019$ & 0,958 \\
\hline Altura & 0,723 & 0,066 & 0,271 & 0,309 & $-0,072$ & 0,844 \\
\hline Tempo diagnóstico & 0,122 & 0,794 & 0,036 & 0,896 & ----- & ----- \\
\hline Linfócitos T & 0,506 & 0,246 & 0,546 & $0,029^{*}$ & 0,553 & 0,097 \\
\hline Linfócitos B & ----- & ----- & ----- & ----- & ----- & ----- \\
\hline $\mathrm{GH}$ & 0,547 & 0,203 & 0,236 & 0,378 & $-0,389$ & 0,266 \\
\hline IGF-I & 0,726 & 0,065 & 0,017 & 0,949 & 0,421 & 0,225 \\
\hline Z(IGF-I) & 0,403 & 0,371 & $-0,036$ & 0,895 & 0,428 & 0,218 \\
\hline IGFBP-3 & 0,834 & $0,020 *$ & 0,461 & 0,072 & 0,118 & 0,746 \\
\hline Z(IGFBP-3) & 0,323 & 0,480 & $-0,008$ & 0,976 & 0,095 & 0,795 \\
\hline IGFBP-2 & $-0,136$ & 0,771 & 0,148 & 0,584 & 0,085 & 0,816 \\
\hline FRTSM & 0,260 & 0,573 & 0,370 & 0,159 & 0,090 & 0,804 \\
\hline PEP C & 0,276 & 0,549 & $-0,345$ & 0,190 & 0,254 & 0,478 \\
\hline
\end{tabular}


Tabela de Correlação - GH

\begin{tabular}{|c|c|c|c|c|c|c|}
\hline & \multicolumn{2}{|c|}{ GRUPO A } & \multicolumn{2}{|c|}{ GRUPO B } & \multicolumn{2}{|c|}{ GRUPO C } \\
\hline & $\mathrm{r}=$ & $\mathrm{p}=$ & $\mathrm{r}=$ & $\mathrm{p}=$ & $\mathrm{r}=$ & $\mathrm{p}=$ \\
\hline Idade & 0,444 & 0,319 & 0,077 & 0,776 & 0,016 & 0,964 \\
\hline Peso & 0,398 & 0,377 & $-0,049$ & 0,856 & 0,001 & 0,998 \\
\hline Altura & 0,453 & 0,308 & 0,034 & 0,901 & 0,070 & 0,847 \\
\hline Tempo diagnóstico & 0,475 & 0,281 & 0,199 & 0,460 & ----- & ----- \\
\hline Linfócitos $\mathrm{T}$ & $-0,133$ & 0,776 & 0,028 & 0,919 & 0,102 & 0,780 \\
\hline Linfócitos B & 0,547 & 0,203 & 0,236 & 0,378 & $-0,389$ & 0,266 \\
\hline $\mathrm{GH}$ & ----- & ----- & ----- & ----- & ----- & ----- \\
\hline IGF-I & 0,275 & 0,550 & 0,397 & 0,128 & $-0,247$ & 0,491 \\
\hline Z(IGF-I) & $-0,062$ & 0,895 & 0,256 & 0,338 & $-0,235$ & 0,514 \\
\hline IGFBP-3 & 0,597 & 0,157 & 0,389 & 0,136 & $-0,018$ & 0,960 \\
\hline Z(IGFBP-3) & $-0,146$ & 0,755 & 0,043 & 0,876 & $-0,184$ & 0,610 \\
\hline IGFBP-2 & $-0,202$ & 0,664 & 0,050 & 0,853 & $-0,147$ & 0,686 \\
\hline FRTSM & 0,476 & 0,280 & $-0,218$ & 0,417 & 0,075 & 0,837 \\
\hline PEP C & 0,081 & 0,863 & 0,194 & 0,471 & $-0,185$ & 0,609 \\
\hline
\end{tabular}


Tabela de Correlação - IGF-I

\begin{tabular}{lcccccc}
\hline & \multicolumn{2}{c}{ GRUPO A } & \multicolumn{2}{c}{ GRUPO B } & \multicolumn{2}{c}{ GRUPO C } \\
\hline & $\mathrm{r}=$ & $\mathrm{p}=$ & $\mathrm{r}=$ & $\mathrm{p}=$ & $\mathrm{r}=$ & $\mathrm{p}=$ \\
\hline Idade & 0,227 & 0,624 & 0,116 & 0,670 & 0,533 & 0,113 \\
Peso & 0,157 & 0,736 & 0,057 & 0,834 & 0,531 & 0,114 \\
Altura & 0,293 & 0,523 & 0,078 & 0,773 & 0,499 & 0,142 \\
Tempo diagnóstico & $-0,041$ & 0,930 & $-0,194$ & 0,471 & ----- & ----- \\
Linfócitos T & 0,310 & 0,499 & 0,013 & 0,961 & 0,588 & 0,074 \\
Linfócitos B & 0,726 & 0,065 & 0,017 & 0,949 & 0,421 & 0,225 \\
GH & 0,275 & 0,550 & 0,397 & 0,128 & $-0,247$ & 0,491 \\
IGF-I & ----- & ----- & ----- & ---- & ----- & ---- \\
Z(IGF-I) & 0,910 & $0,004^{*}$ & 0,895 & $<0,001^{*}$ & 0,941 & $<0,0001^{*}$ \\
IGFBP-3 & 0,519 & 0,233 & 0,653 & $0,006^{*}$ & 0,837 & $0,003 *$ \\
Z(IGFBP-3) & 0,864 & $0,012^{*}$ & 0,167 & 0,536 & $-0,465$ & 0,175 \\
IGFBP-2 & 0,313 & 0,495 & $-0,307$ & 0,248 & $-0,311$ & 0,381 \\
FRTSM & 0,521 & 0,231 & $-0,311$ & 0,242 & 0,370 & 0,292 \\
PEP C & 0,766 & $0,045^{*}$ & 0,146 & 0,589 & 0,504 & 0,137 \\
\hline & & & & & & \\
\hline
\end{tabular}


Tabela de Correlação - Z(IGF-I)

\begin{tabular}{|c|c|c|c|c|c|c|}
\hline & \multicolumn{2}{|c|}{ GRUPO A } & \multicolumn{2}{|c|}{ GRUPO B } & \multicolumn{2}{|c|}{ GRUPO C } \\
\hline & $\mathrm{r}=$ & $\mathrm{p}=$ & $\mathrm{r}=$ & $\mathrm{p}=$ & $\mathrm{r}=$ & $\mathrm{p}=$ \\
\hline Idade & $-0,086$ & 0,854 & $-0,252$ & 0,346 & 0,307 & 0,388 \\
\hline Peso & $-0,145$ & 0,757 & $-0,328$ & 0,215 & 0,278 & 0,436 \\
\hline Altura & $-0,018$ & 0,969 & $-0,281$ & 0,292 & 0,280 & 0,433 \\
\hline Tempo diagnóstico & $-0,259$ & 0,575 & $-0,409$ & 0,116 & ----- & ----- \\
\hline Linfócitos $\mathrm{T}$ & 0,187 & 0,687 & $-0,013$ & 0,961 & 0,511 & 0,131 \\
\hline Linfócitos B & 0,403 & 0,371 & $-0,036$ & 0,895 & 0,428 & 0,218 \\
\hline GH & $-0,062$ & 0,895 & 0,256 & 0,338 & $-0,235$ & 0,514 \\
\hline IGF-I & 0,910 & $0,004^{*}$ & 0,895 & $<0,001^{*}$ & 0,941 & $<0,0001^{*}$ \\
\hline Z(IGF-I) & ----- & ----- & ----- & ----- & ----- & ----- \\
\hline IGFBP-3 & 0,164 & 0,725 & 0,454 & 0,078 & 0,701 & $0,024^{*}$ \\
\hline Z(IGFBP-3) & 0,977 & $<0,0001 *$ & 0,500 & $0,049^{*}$ & $-0,274$ & 0,443 \\
\hline IGFBP-2 & 0,508 & 0,245 & $-0,234$ & 0,384 & $-0,185$ & 0,609 \\
\hline FRTSM & 0,418 & 0,351 & $-0,472$ & 0,065 & 0,200 & 0,579 \\
\hline PEP C & 0,841 & $0,018^{*}$ & 0,080 & 0,770 & 0,426 & 0,219 \\
\hline
\end{tabular}


Tabela de Correlação - IGFBP-3

\begin{tabular}{|c|c|c|c|c|c|c|}
\hline & \multicolumn{2}{|c|}{ GRUPO A } & \multicolumn{2}{|c|}{ GRUPO B } & \multicolumn{2}{|c|}{ GRUPO C } \\
\hline & $\mathrm{r}=$ & $\mathrm{p}=$ & $\mathrm{r}=$ & $\mathrm{p}=$ & $\mathrm{r}=$ & $\mathrm{p}=$ \\
\hline Idade & 0,795 & $0,033^{*}$ & 0,416 & 0,109 & 0,858 & $0,001 *$ \\
\hline Peso & 0,725 & 0,065 & 0,442 & 0,087 & 0,845 & $0,002 *$ \\
\hline Altura & 0,814 & $0,026^{*}$ & 0,323 & 0,222 & 0,853 & $0,002 *$ \\
\hline Tempo diagnóstico & 0,365 & 0,420 & 0,048 & 0,860 & ----- & ----- \\
\hline Linfócitos $\mathrm{T}$ & 0,628 & 0,131 & 0,124 & 0,647 & 0,385 & 0,272 \\
\hline Linfócitos B & 0,834 & $0,020 *$ & 0,461 & 0,072 & 0,118 & 0,746 \\
\hline $\mathrm{GH}$ & 0,597 & 0,157 & 0,389 & 0,136 & $-0,018$ & 0,960 \\
\hline IGF-I & 0,519 & 0,233 & 0,653 & $0,006^{*}$ & 0,837 & $0,003^{*}$ \\
\hline Z(IGF-I) & 0,164 & 0,725 & 0,454 & 0,078 & 0,701 & $0,024 *$ \\
\hline IGFBP-3 & ----- & ----- & ----- & ----- & ----- & ----- \\
\hline Z(IGFBP-3) & 0,185 & 0,691 & 0,112 & 0,679 & $-0,795$ & $0,006^{*}$ \\
\hline IGFBP-2 & $-0,390$ & 0,387 & $-0,423$ & 0,103 & $-0,620$ & 0,056 \\
\hline FRTSM & 0,530 & 0,221 & 0,313 & 0,238 & 0,377 & 0,283 \\
\hline PEP C & 0,120 & 0,798 & $-0,133$ & 0,622 & 0,473 & 0,167 \\
\hline
\end{tabular}


Tabela de Correlação - Z(IGFBP-3)

\begin{tabular}{|c|c|c|c|c|c|c|}
\hline & \multicolumn{2}{|c|}{ GRUPO A } & \multicolumn{2}{|c|}{ GRUPO B } & \multicolumn{2}{|c|}{ GRUPO C } \\
\hline & $\mathrm{r}=$ & $\mathrm{p}=$ & $\mathrm{r}=$ & $\mathrm{p}=$ & $\mathrm{r}=$ & $\mathrm{p}=$ \\
\hline Idade & $-0,105$ & 0,823 & $-0,820$ & $<0,0001 *$ & $-0,899$ & $<0,0001^{*}$ \\
\hline Peso & $-0,175$ & 0,707 & $-0,775$ & $<0,0001 *$ & $-0,855$ & $0,002 *$ \\
\hline Altura & $-0,038$ & 0,935 & $-0,872$ & $<0,0001^{*}$ & $-0,930$ & $<0,0001^{*}$ \\
\hline Tempo diagnóstico & $-0,241$ & 0,603 & $-0,555$ & $0,026^{*}$ & ----- & ----- \\
\hline Linfócitos $\mathrm{T}$ & 0,254 & 0,582 & $-0,108$ & 0,692 & $-0,338$ & 0,339 \\
\hline Linfócitos B & 0,323 & 0,480 & $-0,008$ & 0,976 & 0,095 & 0,795 \\
\hline $\mathrm{GH}$ & $-0,146$ & 0,755 & 0,043 & 0,876 & $-0,184$ & 0,610 \\
\hline IGF-I & 0,864 & $0,012^{*}$ & 0,167 & 0,536 & $-0,465$ & 0,175 \\
\hline Z(IGF-I) & 0,977 & $<0,0001^{*}$ & 0,500 & $0,049^{*}$ & $-0,274$ & 0,443 \\
\hline IGFBP-3 & 0,185 & 0,691 & 0,112 & 0,679 & $-0,795$ & $0,006^{*}$ \\
\hline Z(IGFBP-3) & ----- & ----- & ----- & ----- & ----- & ----- \\
\hline IGFBP-2 & 0,488 & 0,266 & $-0,052$ & 0,849 & 0,604 & 0,065 \\
\hline FRTSM & 0,476 & 0,280 & $-0,296$ & 0,266 & $-0,655$ & $0,040^{*}$ \\
\hline PEP C & 0,843 & $0,017^{*}$ & $-0,105$ & 0,698 & $-0,295$ & 0,408 \\
\hline
\end{tabular}


Tabela de Correlação - IGFBP-2

\begin{tabular}{|c|c|c|c|c|c|c|}
\hline & \multicolumn{2}{|c|}{ GRUPO A } & \multicolumn{2}{|c|}{ GRUPO B } & \multicolumn{2}{|c|}{ GRUPO C } \\
\hline & $\mathrm{r}=$ & $\mathrm{p}=$ & $r=$ & $\mathrm{p}=$ & $\mathrm{r}=$ & $\mathrm{p}=$ \\
\hline Idade & $-0,776$ & $0,040^{*}$ & $-0,180$ & 0,504 & $-0,538$ & 0,108 \\
\hline Peso & $-0,787$ & $0,036^{*}$ & $-0,174$ & 0,519 & $-0,503$ & 0,138 \\
\hline Altura & $-0,744$ & 0,055 & $-0,096$ & 0,723 & $-0,578$ & 0,080 \\
\hline Tempo diagnóstico & $-0,299$ & 0,515 & 0,181 & 0,501 & ----- & ----- \\
\hline Linfócitos T & $-0,553$ & 0,198 & 0,043 & 0,873 & 0,214 & 0,553 \\
\hline Linfócitos B & $-0,136$ & 0,771 & 0,148 & 0,584 & 0,085 & 0,816 \\
\hline $\mathrm{GH}$ & $-0,202$ & 0,664 & 0,050 & 0,853 & $-0,147$ & 0,686 \\
\hline IGF-I & 0,313 & 0,495 & $-0,307$ & 0,248 & $-0,311$ & 0,381 \\
\hline $\mathrm{Z}(\mathrm{IGF}-\mathrm{I})$ & 0,508 & 0,245 & $-0,234$ & 0,384 & $-0,185$ & 0,609 \\
\hline IGFBP-3 & $-0,390$ & 0,387 & $-0,423$ & 0,103 & $-0,620$ & 0,056 \\
\hline Z(IGFBP-3) & 0,488 & 0,266 & $-0,052$ & 0,849 & 0,604 & 0,065 \\
\hline IGFBP-2 & ----- & ----- & ----- & ----- & ----- & ----- \\
\hline FRTSM & $-0,191$ & 0,681 & $-0,146$ & 0,591 & $-0,021$ & 0,954 \\
\hline PEP C & 0,795 & $0,033^{*}$ & $-0,471$ & 0,066 & 0,036 & 0,922 \\
\hline
\end{tabular}


Tabela de Correlação - FRTSM

\begin{tabular}{|c|c|c|c|c|c|c|}
\hline & \multicolumn{2}{|c|}{ GRUPO A } & \multicolumn{2}{|c|}{ GRUPO B } & \multicolumn{2}{|c|}{ GRUPO C } \\
\hline & $\mathrm{r}=$ & $\mathrm{p}=$ & $r=$ & $\mathrm{p}=$ & $\mathrm{r}=$ & $\mathrm{p}=$ \\
\hline Idade & 0,295 & 0,520 & 0,545 & $0,029^{*}$ & 0,536 & 0,110 \\
\hline Peso & 0,179 & 0,701 & 0,630 & $0,009^{*}$ & 0,497 & 0,144 \\
\hline Altura & 0,336 & 0,461 & 0,488 & 0,055 & 0,527 & 0,117 \\
\hline Tempo diagnóstico & 0,449 & 0,312 & 0,388 & 0,137 & ----- & ----- \\
\hline Linfócitos $\mathrm{T}$ & 0,215 & 0,643 & 0,277 & 0,299 & 0,695 & $0,026^{*}$ \\
\hline Linfócitos B & 0,260 & 0,573 & 0,370 & 0,159 & 0,090 & 0,804 \\
\hline $\mathrm{GH}$ & 0,476 & 0,280 & $-0,218$ & 0,417 & 0,075 & 0,837 \\
\hline IGF-I & 0,521 & 0,231 & $-0,311$ & 0,242 & 0,370 & 0,292 \\
\hline Z(IGF-I) & 0,418 & 0,351 & $-0,472$ & 0,065 & 0,200 & 0,579 \\
\hline IGFBP-3 & 0,530 & 0,221 & 0,313 & 0,238 & 0,377 & 0,283 \\
\hline Z(IGFBP-3) & 0,476 & 0,280 & $-0,296$ & 0,266 & $-0,655$ & $0,040 *$ \\
\hline IGFBP-2 & $-0,191$ & 0,681 & $-0,146$ & 0,591 & $-0,021$ & 0,954 \\
\hline FRTSM & ----- & ----- & ----- & ----- & ----- & ----- \\
\hline PEP C & 0,341 & 0,454 & $-0,538$ & $0,032 *$ & 0,402 & 0,249 \\
\hline
\end{tabular}


Tabela de Correlação - PEP C

\begin{tabular}{|c|c|c|c|c|c|c|}
\hline & \multicolumn{2}{|c|}{ GRUPO A } & \multicolumn{2}{|c|}{ GRUPO B } & \multicolumn{2}{|c|}{ GRUPO C } \\
\hline & $\mathrm{r}=$ & $\mathrm{p}=$ & $r=$ & $\mathrm{p}=$ & $r=$ & $\mathrm{p}=$ \\
\hline Idade & $-0,348$ & 0,444 & $-0,124$ & 0,647 & 0,568 & 0,087 \\
\hline Peso & $-0,416$ & 0,353 & $-0,137$ & 0,613 & 0,513 & 0,129 \\
\hline Altura & $-0,289$ & 0,530 & $-0,116$ & 0,669 & 0,508 & 0,134 \\
\hline Tempo diagnóstico & $-0,196$ & 0,674 & $-0,368$ & 0,161 & ----- & ----- \\
\hline Linfócitos T & $-0,141$ & 0,763 & $-0,271$ & 0,311 & 0,601 & 0,066 \\
\hline Linfócitos B & 0,276 & 0,549 & $-0,345$ & 0,190 & 0,254 & 0,478 \\
\hline $\mathrm{GH}$ & 0,081 & 0,863 & 0,194 & 0,471 & $-0,185$ & 0,609 \\
\hline IGF-I & 0,766 & $0,045^{*}$ & 0,146 & 0,589 & 0,504 & 0,137 \\
\hline Z(IGF-I) & 0,841 & $0,018^{*}$ & 0,080 & 0,770 & 0,426 & 0,219 \\
\hline IGFBP-3 & 0,120 & 0,798 & $-0,133$ & 0,622 & 0,473 & 0,167 \\
\hline Z(IGFBP-3) & 0,843 & $0,017^{*}$ & $-0,105$ & 0,698 & $-0,295$ & 0,408 \\
\hline IGFBP-2 & 0,795 & $0,033^{*}$ & $-0,471$ & 0,066 & 0,036 & 0,922 \\
\hline FRTSM & 0,341 & 0,454 & $-0,538$ & $0,032 *$ & 0,402 & 0,249 \\
\hline PEP C & ----- & ----- & ----- & ----- & ----- & ----- \\
\hline
\end{tabular}


Tabela de Mediana e DSQ

\begin{tabular}{|c|c|c|c|c|c|c|c|c|c|}
\hline & \multicolumn{3}{|c|}{ GRUPO A } & \multicolumn{2}{|c|}{ GRUPO B } & \multicolumn{3}{|c|}{ GRUPO C } & \multirow{2}{*}{$\frac{\text { Comparação }}{\mathrm{p}}$} \\
\hline & $\mathrm{Md}$ & \pm & DSQ & Md & $\pm \mathrm{DSQ}$ & $\mathrm{Md}$ & \pm & DSQ & \\
\hline Idade & 5,50 & & 2,45 & 8,37 & 1,06 & 9,00 & & 1,16 & $0,006^{*}$ \\
\hline Peso & 18,70 & & 5,05 & 24,60 & 4,40 & 30,10 & & 4,23 & $0,008^{*}$ \\
\hline Altura & 111,00 & & 16,50 & 126,25 & 6,75 & 132,00 & & 6,69 & $0,005^{*}$ \\
\hline $\begin{array}{l}\text { Tempo } \\
\text { diagnóstico }\end{array}$ & 3,00 & & 2,12 & 56,00 & 26,25 & ----- & & ----- & $<0,0001 *$ \\
\hline Linfócitos T & 0,73 & & 0,03 & 0,72 & 0,06 & 0,72 & & 0,11 & 0,963 \\
\hline Linfócitos B & 0,86 & & 0,21 & 0,65 & 0,08 & 0,52 & & 0,05 & $0,002 *$ \\
\hline $\mathrm{GH}$ & 0,26 & & 0,28 & 0,22 & 1,07 & 1,70 & & 2,10 & 0,256 \\
\hline IGF-I & 252,00 & & 224,4 & 349,20 & 110,10 & 457,20 & & 229,80 & 0,364 \\
\hline Z(IGF-I) & 0,72 & & 2,04 & 0,99 & 1,44 & 1,36 & & 1,72 & 0,894 \\
\hline IGFBP-3 & 3,95 & & 0,82 & 4,63 & 0,58 & 4,88 & & 0,57 & 0,416 \\
\hline Z(IGFBP-3) & 3,51 & & 3,41 & 1,87 & 0,89 & 1,40 & & 0,66 & $0,040^{*}$ \\
\hline IGFBP-2 & 528,41 & & 157,15 & 493,95 & 192,67 & 516,24 & & 144,02 & 0,837 \\
\hline FRTSM & 365,90 & & 62,05 & 444,25 & 68,27 & 239,40 & & 24,57 & $<0,0001^{*}$ \\
\hline PEP C & 0,70 & & 0,60 & 0,75 & 0,46 & 2,25 & & 0,98 & $0,002 *$ \\
\hline
\end{tabular}

* teste aplicado: Kruskal-Wallis 
Tabela de Mediana e Quartis

\begin{tabular}{|c|c|c|c|c|c|c|c|c|c|}
\hline & \multicolumn{3}{|c|}{ GRUPO A } & \multicolumn{3}{|c|}{ GRUPO B } & \multicolumn{3}{|c|}{ GRUPO C } \\
\hline & Q1 & Md & Q3 & Q1 & Md & Q3 & Q1 & Md & Q3 \\
\hline Idade & 1,92 & 5,50 & 6,83 & 7,37 & 8,37 & 9,50 & 6,89 & 9,00 & 9,22 \\
\hline Peso & 11,90 & 18,70 & 22,00 & 21,87 & 24,60 & 30,67 & 23,70 & 30,10 & 32,17 \\
\hline Altura & 85,50 & 111,00 & 118,50 & 120,37 & 126,25 & 133,87 & 121,87 & 132,00 & 135,25 \\
\hline $\begin{array}{l}\text { Tempo } \\
\text { diagnóstico }\end{array}$ & 0,75 & 3,00 & 5,00 & 31,50 & 56,00 & 84,00 & ----- & ----- & ----- \\
\hline Linfócitos $\mathrm{T}$ & 0,68 & 0,73 & 0,75 & 0,66 & 0,72 & 0,79 & 0,60 & 0,72 & 0,82 \\
\hline Linfócitos B & 0,58 & 0,86 & 1,00 & 0,58 & 0,65 & 0,75 & 0,47 & 0,52 & 0,57 \\
\hline $\mathrm{GH}$ & 0,13 & 0,26 & 0,69 & 0,08 & 0,22 & 2,22 & 0,12 & 1,70 & 4,33 \\
\hline IGF-I & 163,20 & 252,00 & 612,00 & 253,20 & 349,20 & 473,40 & 279,00 & 457,20 & 738,60 \\
\hline $\mathrm{Z}(\mathrm{IGF}-\mathrm{I})$ & 0,20 & 0,72 & 4,28 & $-0,14$ & 0,99 & 2,75 & $-0,009$ & 1,36 & 3,45 \\
\hline IGFBP-3 & 3,38 & 3,95 & 5,02 & 4,11 & 4,63 & 5,27 & 4,07 & 4,88 & 5,22 \\
\hline Z(IGFBP-3) & 2,11 & 3,51 & 8,93 & 1,05 & 1,87 & 2,84 & 0,99 & 1,40 & 2,31 \\
\hline IGFBP-2 & 358,73 & 528,41 & 673,04 & 318,33 & 493,95 & 703,68 & 293,73 & 516,24 & 581,77 \\
\hline FRTSM & 286,30 & 365,90 & 410,40 & 371,67 & 444,25 & 508,22 & 198,22 & 239,40 & 247,37 \\
\hline PEP C & 0,50 & 0,70 & 1,70 & 0,35 & 0,75 & 1,27 & 1,25 & 2,25 & 3,22 \\
\hline
\end{tabular}




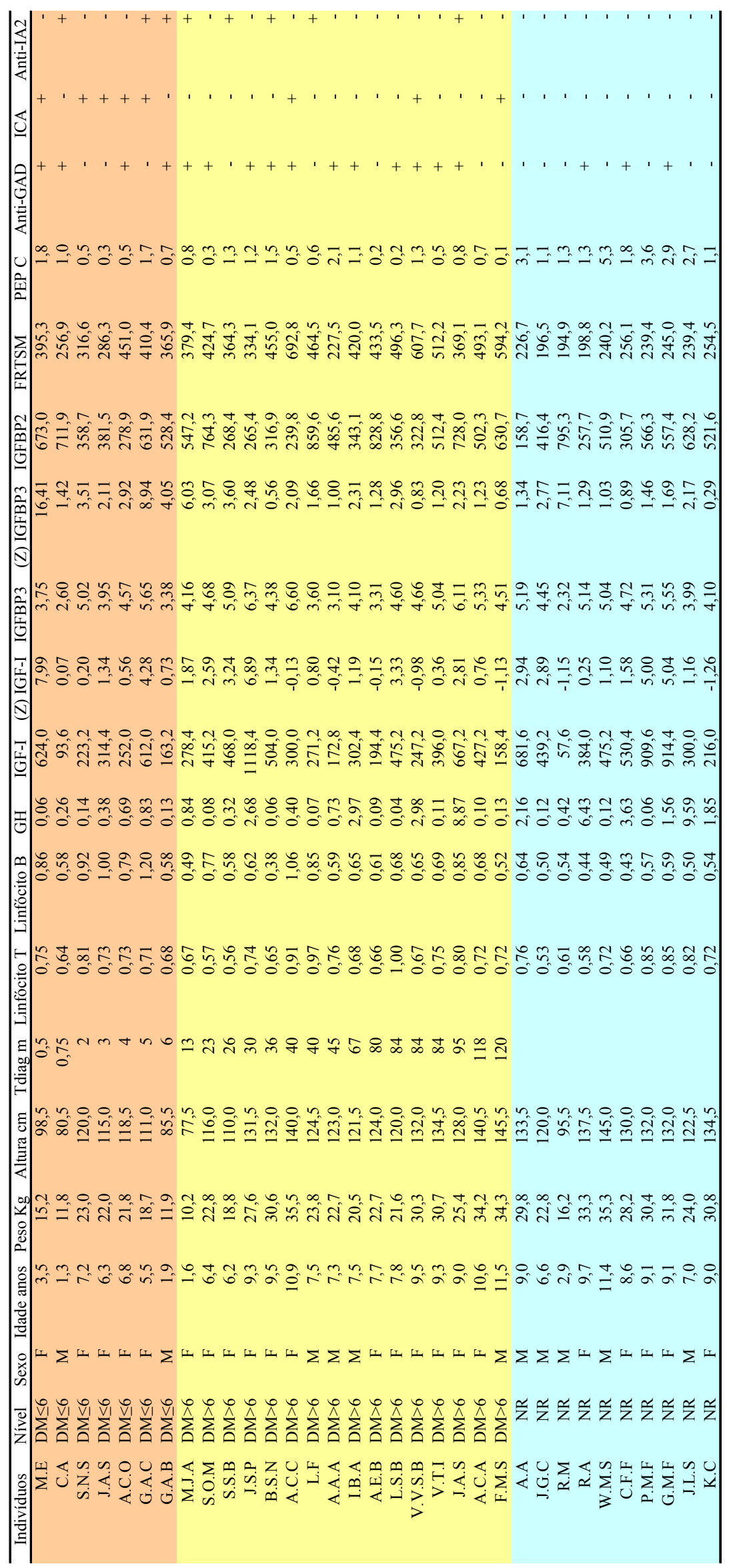




\section{REFERÊNCIAS BIBLIOGRÁFICAS}

1. ATKINSON MA, BOWMAN MA, KAO K-J, CAMPBELL L, AUSH PJ et al. Lack of immune responsiveness to bovine serum albumin in insulin-dependent diabetes mellitus. N Engl J Med, v.329, p.1853-1858, 1993.

2. ATKINSON MA, EISENBARTH GS. Type 1 diabetes: new perspectives on disease pathogenesis and treatment. Lancet, v.358, p.221-229, 2001.

3. BACH LA, RECHLER MM. Insulin-like growth factor binding proteins. Diabetes Reviews, v.3, p.38-61, 1995.

4. BAEKKESKOV S, AANSTOOT H-J, CHRISTGAU S, REETZ A, SOLIMENA $\mathrm{M}$, CASCALHO $\mathrm{M}$ et al. Identification of the $64 \mathrm{~K}$ Autoantigen in InsulinDependent Diabetes as the GABA-Synthesizing Enzyme Glutamic Acid Descarboxylase. Nature, v.347, p.151-156, 1990.

5. BALASUBRAMANYAM M, PREMANAND C, MOHAN V. The Lymphocyte as a Cellular Model to Study Insights into the Pathophysiology of Diabetes and Its Complications. Ann. N.Y. Acad. Sci, v.958, p.399-402, 2002.

6. BARONI C. Thymus, peripheral lymphoid tissues and immunological responsiveness of the pituitary dwarf mouse. Experientia, v.23, p.282-283, 1967.

7. BERKET A, LANG CH, WILSON TA. Alterations in the growth-hormone-insulinlike growth factor axis in insulin dependent diabetes mellitus. Hormone and Metabolic Research, v.31, p.172-181, 1999. 
8. BINGLEY PJ, BONIFACIO E, WILLIAMS AJ, GENOVESE S, BOTTAZZO GF et al. Prediction of IDDM in the general population: strategies based on combinations of autoantibody markers. Diabetes, v.46, p.1701-1710, 1997.

9. BORG H, GOTTSATER A, LANDIN-OLSSON M, FERNLUND P, SUNDKVIST G. High levels of antigen-specific islet antibodies predict future beta-cell failure in patients with onset of diabetes in adult age. J Clin Endocrinol Metab, v.86, p.3032-3038, 2001.

10. BOTAZZO G, FLORIN-CHRISTENSEN A, DONIACH D. Islet Cell Antibodies in Diabetes Mellitus with Autoimmune PolyendocrineDeficiences. Lancet, november, p.1279-1282, 1974.

11. BOTTINO R, LEMARCHAND P, TRUCCO M, GIANNOUKAKIS N. Gene- and cell-based therapeutics for type 1 diabetes mellitus. Gene Therapy, v.10, p.875889, 2003.

12. BRACCO O L. Avaliação do eixo do Hormônio de crescimento durante o desenvolvimento ontogenético humano até a senilidade. São Paulo, 1997.133p. Dissertação (Mestrado) - Faculdade de Medicina - USP.

13. BUCKBINDER L, TALLBOTT R, VELASCO-MIGUEL S, TAKENAKA I, FAHA B, SEIZINGER BR, KLEY N. Induction of the growth inhibitor IGFbinding protein 3 by p53. Nature, v.377, p.646-649, 1995.

14. CLAIRE E, STEWART H, ROTWEIN P. Growth, Differentiation, and Survival: Multiple Physiological Functions of Insulin-like growth factors. Physiological Reviews, v.76, p.1005-1026, 1996.

15. CLARK R. The Somatogenic Hormones and Insulin-Like Growth Factor-1: Stimulators of Lymphopoiesis and Immune function. Endocrine Reviews, v.18 (2), p.157-179, 1997. 
16. DECOCHEZ K, KEYMEULEN B, SOMERS G, DORCHY H et al. Use of an islet cell antibody assay to identify type 1 diabetic patients with rapid decrease in Cpeptide levels after clinical onset - Belgian Diabetes Registry. Diabetes Care, v.23, p.1072-1078, 2000.

17. DOTTA F, EISENBARTH S. Immunopathogenesis of Insulin-Dependent Diabetes Mellitus. International Textbook of Diabetes Mellitus, 2nd adn, v.01, p.97-108, 1997.

18. EKMAN B, NYSTROM F, ARNGVIST HJ. Circulating IGF-I levels are low and not correlated to glycemic control in adults with type 1 diabetes mellitus. European Journal of Endocrinology, v.143, p.505-510, 2000.

19. EVERITT AV, CAVANAGH LM. The aging process in the hypophysectomised rat. Gerontologia, v.11, p.198-207, 1965.

20. FEENEY SJ, MYERS MA, MACKAY I et al. Evaluation of ICA512Ab in combination with other islet cell autoantibodies at the onset of IDDM. Diabetes Care, v.20, p.1403-1407, 1997.

21. FERREIRA SR, FRANCO LJ, VIVOLO MA, NEGRATO GA, SIMOES AC, VENTURELLI CR. Population based incidence of IDDM in the state of São Paulo, Brazil. Diabetes Care, v.16, p.701-704, 1993.

22. FIRTH S, BAXTER R. Cellular Actions of the Insulin-Like Growth Factor Binding Proteins. Endocrine Reviews, v.23 (6), p.824-854, 2002.

23. FOSTER MP, JENSEN ER, MONTECINO-RODRIGUEZ E, LEATHERS H, HORSEMAN N, DORSHKIND K. Humoral and cell-mediated immunity in mice with genetic deficiencies of prolactin, growth hormone, insulin-like growth factor-I, and thyroid hormones. Clin Immunol, v.74, p.59-72, 2000.

24. GALE EA: The discovery of type 1 diabetes. Diabetes, v.50, p.217-226, 2001. 
25. GENOVESE S, BONIFACIO E, MCNALLY M, DEAN M, WAGNER R, BOSI E, GALE M, BOTTAZZO F. Distinct Cytoplasmic Islet Cell Antibodies with Differents Risks for Type 1(Insulin-Dependent) Diabetes Mellitus. Diabetologia, v.35, p.385, 1992.

26. HANAIRE-BROUTIN H, SALLERIN-CAUTE B, PONCET MF, TAUBER M, BASTIDE R, CHALÉ JJ, ROSENFELD R, TAUBER JP. Effect of intraperitoneal insulin delivery on growth hormone binding protein, insulin-like growth factor IGF-I, and IGF-binding protein-3 in IDDM. Diabetologia, v.39, p.1498-1504, 1996.

27. HARRIS A. Insulin-like growth factors in human breast cancer. Breast Cancer Research and Treatment, v.52, p.175-184, 1988.

28. HARRISON LC, HONEYMAN MC, et al. Inverse relationship between humoral and cellular immunity to glutamic acid decarboxylase in subjects at risk of insulindependent diabetes. Lancet, v.341, p.1365-1369, 1993.

29. HOLLOWOOD AD, LAI T, PERKS CM, NEWCOMB PV, ALDERSON D, HOLLY JM. IGFBP3 prolongs the p53 response and enhances apoptosis following UV irradiation. International Journal of Cancer, v.88, p.336-341, 2000.

30. HYOTY H, HILTUNEN M, KNIP M, et al. Childhood diabetes in finland study group. A Prospective Study of the Role of Coxasackie B and other Enterovirus Infections in the Patogenesis of IDDM. Diabetes, v.44, p.652-657, 1995.

31. IRWIN JC, SUEN LF, FAESSEN GH, POPOVICI RM, GIUDICE LC. Insulin-like growth factor (IGF)-II inhibition of endometrial stromal cell tissue inhibitor of metalloproteinase-3 and IGF-binding protein-1 suggests paracrine interactions at the decidua: trophoblast interface during human implantation. J Clin Endocrinol Metab, v.86, p.2060-2064, 2001.

32. JANEWAY C, TRAVERS P, WALPORT M, SHLOMCHIK. Imunobiologia: O sistema imune na saúde e na doença. 5 ed. Artmed Editora, p.21-55, 2002. 
33. JARDIEU P, CLARK R, MORTENSEN D, DORSHKIND K. In vivo administration of IGF-I stimulates primary B lymphopoiesis and enhances lymphocyte recovery after bone marrow transplantation. Journal of Immunology, v.152, p.4320-4327, 1994.

34. JIN-XIONG S. Susceptibility to Type 1 Diabetes: HLA-DQ and DR Revisited. Immunology Today, v.17, p.323-329, 1996.

35. JONES JI, CLEMMONS DR. Insulin like growth factors and their binding proteins: Biological actions. Endocrine Reviews, v.16, p. 03-34, 1995.

36. KARVONEN M, PITKNIEMI M, PITKNIEMI J, et al. Sex Difference in the Incidence of Insulin-Dependent Diabetes Mellitus: Analysis of the Recent Epidemiological Data. Diabetes Metab Rev, v.13, p.275-291, 1997.

37. KARVONEN M, TUOMILEHTO J, LIBMAN I, LAPORTE R. A Review of the Recent Epidemiological Data on the Worldwide Incidence of Type 1(InsulinDependent) Diabetes Mellitus. Diabetologia, v.36, p.883-892, 1993.

38. KELLEY KW, ARKINS S, MINSHALL C, LIU Q, DANTZER R. Growth Hormone, Growth Factors and Hematopoiesis. Hormone Research, v.45, p. 38-45, 1996.

39. KIM HS, NAGALLA SR, OH Y, WILSON E, ROBERTS CT, ROSENFELD RG. Identification of a family of low-affinity insulin-like growth factor binding proteins (IGFBPs): characterization of connective tissue growth factor as a member of the IGFBP superfamily. Protocols of National Academical Sciences, v.94, p.1298112986, 1997.

40. KLEIN J, SATO A. The HLA System-First of two Parts. N Engl J Med, v.343, p.702-786, 2000.

41. KOLB H, DANNEHL $\mathrm{K}$, GRUNEKLEE D, ZIELASEK J, BERTRAMS J, HUBINGER A, GRIES FA. Prospective analysis of islet cell antibody in children with type I (insulin-dependent) diabetes. Diabetologia, v.31, p.184-194, 1988. 
42. KOOIJMAN R, WILLEMS M, DE HAAS CJ, RIJKERS GT, SCHUURMANS AL et al. Expression of type I insulin-like growth factor receptors on human peripheral blood mononuclear cells. Endocrinology, v.131, p.2244-2250, 1992.

43. KULMALA P, SAVOLA K, PETERSEN JS, VAHASALO P, KARJALAINEN J, LOPPONEN T, DYRBERG T, AKERBLOM HK, KNIP M. Prediction of insulindependent diabetes mellitus in siblings of children with diabetes. A populationbased study. The Childhood Diabetes in Finland Study Group. J Clin Invest, v.101, p.327-336, 1998.

44. LAN MS, LU J, GOTO Y, NOTKINS AL. Molecular cloning and identification of a receptor-type protein tyrosine phosphatase IA-2 from human insulinoma. DNA Cell Biol, v.13, p.505-514, 1994.

45. LANDRETH K, NARAYANAN R, DORSHKIND K. IGF-I regulates pro-B cell differentiation. Blood, v.80, p.1207-1210, 1992.

46. LE ROITH D, BONDY C, YAKAR S, LIU J, BUTLER A. The Somatomedin Hypothesis: 2001. Endocrine Reviews, v.22 (1), p.53-74, 2001.

47. LENMARK A. Type 1 diabetes. Clin Chem, v.45, p.1331-1338, 1999.

48. LESLIE RD, ATKINSON MA, NOTKINS AL. Autoantigens IA-2 and GAD in type I (insulin-dependent) diabetes. Diabetologia, v.42, p.13-14, 1999.

49. LI S, CRESHAW EB, RAWSON EJ, SIMMONS DM, SWANSON LW, ROSEFELD MG. Dwarf locus mutants lacking three pituitary cell types result from mutations in the pou-domain gene pit-1. Nature, v. 347, p.528-533, 1990.

50. LIN SC, LIN CR, GUKOVSKY I, LUSIS AJ, SAWCHENKO PE, ROSENFELD MG. Molecular basis of the little mouse phenotype and implications for cell typespecific growth. Nature, v.364, p.208-213, 1993.

51. LIU JP, BAKER J, PERKINS AS, ROBERSTON EF, EFSTRATIADIS A. Mice carrying null mutations of the genes encoding insulin-like growth factor I (IGF-I) and type 1 IGF receptor (IGF1r). Cell, v.75, p.59-72, 1993. 
52. LUDVIGSSON J, HELLSTROM S. Autoantibodies in relation to residual insulin secretion in children with IDDM. Diabetes Res Clin Pract, v.35, p.81-89, 1997.

53. MACAULAY VM. Insulin-like growth factors and cancer. British Journal of Cancer, v.65, p. 311-320, 1992.

54. MANDRUP-POULSEN T, BENDTZEN K, NIELSEN JH, BENDIXEN G, NERUP J. Cytoquines cause functional and structural damage to isolated islets of Langerhans. Allergy, v.40, p.424-429, 1985.

55. MARTIN JM, KARJALAINEN J, KNIP $M$ et al. A bovine albumin peptide as a possible trigger of insulin-dependent diabetes mellitus. N Engl J Med, v.327, p.302-307, 1992.

56. MARTIN S, WOLF R, DUINKERKEN G, SCHERBAUM WA, KOLB H, NOORDZIJ JG, ROEP BO. Development of type 1 diabetes in severe hereditary Blymphocyte deficiency. N Engl J Med, v.345, p.1060-1061, 2001.

57. MAURICIO D, CARRERAS G, PÉREZ A, MORALES J, PUIG-DOMINGO M, LEIVA A. Association of islet-cell and glutamic-acid decarboxylase antibodies to [beta]-cell function after the onset of type 1 diabetes in adult subjects. Diabet Nutr Metab, v.10, p.189-192, 1997.

58. McCULLOCH DK, KOERKER MJ, KAHN SE, BONNER-WEIR S, PALMER JP. Correlation of in vivo- $\beta$-cell function tests with B cells masss and pancreatic insulin content in streptozotocin treated baboons. Diabetes, v.40, p.673-679, 1991.

59. McDEVITT H. Autoimmune Diabetes and Its Antigenic Trigenic Triggers. Hospital Practice, p.55-62, July 15, 1995.

60. MONTECINO-RODRIGUEZ E, CLARK RG, POWELL-BRAXTON L, DORSHKIND K. Primary B Cell development is impaired in mice with defects of the pituitary/thyroid axis. J Immunol, v.159, p.2712-2719, 1997.

61. MUNTONI S, STABILINI L, MANCOSU G, MUNTONI S. Steadily High IDDM Incedence Over 4 Year in Sardinia. Diabetes Care, v.18, p.1600-1601, 1995. 
62. NERUP J, MANDRUP-POULSEN T, MOLVIG J. The HLA-IDDM association: implications for etiology and pathogenesis of IDDM. Diabetes Metab. Rev, v.3, p.779-802, 1987.

63. NOBLE A, VALDES M, COOK M, KLITZ W, THOMSON G, ERLICH A. The role of HLA Class II genes in insulin-Dependent Diabetes mellitus: Molecular Analysis of 180 Caucasian, Multiplex Families. Am. J. Hum. Genet, v.59, p.11341148, 1996.

64. OWERBACH D, GABBAY KH. Localization of a type 1 diabetes susceptibility locus to the variable tandem repeat region flanking the insulin gene. Diabetes, v.42, p.1708-1714, 1993.

65. PETERSEN JS, DYRBERG T, KARLSEN AE, MOLVIG J, MICHELSEN B ET AL. Glutamic acid decarboxylase (GAD65) autoantibodies in prediction of betacell function and remission in recent-onset IDDM after cyclosporin treatment. The Canadian-European Randomized Control Trial Group. Diabetes , v.43, p.12911296, 1994.

66. POLONSKY KS, GIVEN BD \& VAN CAUTER E. Twenty-four-hour profiles and pulsatile patterns of insulin secretion in normal and obese subjects. Journal of Clinical Investigation, v.81, p.442-448, 1988.

67. RABONOVITCH A. Immunoregulatory and cytokine imbalances in the pathogenesis of IDDM. Diabetes, v. 43, p.613-621, 1994.

68. RAJAH R, VALENTINIS B, COHEN P. Insulin like growth factor (IGF)-binding protein-3 induces apoptosis and mediates the effects of transforming growth factor[beta]1 on programmed cell death through a p53- and IGF-independent mechanism. J Biol Chem, v.272, p.12181-12188, 1997.

69. RECHLER M. Insulin-like growth factor binding proteins. Vitam Horm, v.47, p.1$114,1993$. 
70. REISS K, PORCU P, SELL C, PIETRZKOWSKI Z, BASERGA, R. The insulin like growth factor 1 receptor is required for the proliferation of hemopoietic cells. Oncogene, v.7, p.2243-2248, 1992.

71. ROEP BO, KOLB H, MARTIN S. B-cell deficiency and type 1 diabetes (Letter). $\mathbf{N}$ Engl J Med, v.346, p.538-539, 2002.

72. ROLDAN A, CHARREAU E, SHILLACI R, EUGUI M, ALLISON C. Insulin-like growth factor 1 increases the mitogenic response of human peripheral blood lymphocytes to phytohemagglutinin. Immunology Letters, v.20, p.05-08, 1989.

73. ROSENFELD R. Disorders of growth hormone and insulin-like growth factor secretion and action. In: SPERLING M. Pediatric Endocrinology. Philadelphia, W.B.Saunders, p.117-169, 1996.

74. RUBIN R, BASERGA R. Biology of disease: Insulin-like growth factors receptors. Its role in cell proliferation, apoptosis and tumorogenicity. Lab Investigation, v.73, p.311-329, 1995.

75. SABBAH E, SAVOLA $K$, KULMALA P, VEIJOLA R, VAHASALO $P$, KARJALAINEN J, AKERBLOM HK, KNIP M. Diabetes-associated autoantibodies in relation to clinical characteristics and natural course in children with newly diagnosed type 1 diabetes. The Childhood Diabetes In Finland Study Group. J Clin Endocrinol Metab, v.84, p.1534-1539, 1999.

76. SALMON WD, DAUGHADAY WH. A hormonnally controlled serum factor which stimulates sulfate incorporation by cartilage in vitro. J Lab Clin Med, v.49, p.825-826, 1957.

77. SARA V, HALL K. Insulin like growth factors and their binding proteins. Physiological Reviews, v.70, p.591-602, 1990.

78. SEISSLER J, DE SONNAVILLE JJ, MORGENTHALER NG, STEINBRENNER H, GLAWE D et al. Immunological heterogeneity in type I diabetes: presence of distinct autoantibody patterns in patients with acute onset and slowly progressive disease. Diabetologia, v.41, p.891-897, 1998. 
79. SHIMON I, SHPILBERG O. The insulin-like growth factor system in regulation of normal and malignant hematopoiesis. Leukemia Research, v.19, p. 233-240, 1995.

80. SJOGREN K, LIU JL, BLAD K, SKRTIC S, VIDAL O, WALLENIUS V, LEROITH D, TORNELL J, ISAKSSON OG, JANSSON JO, OHLSSON C. Liverderived insulin-like growth factor I (IGF-I) is the principal source of IGF-I in blood but is not required for postnatal body growth in mice. Proc Natl Acad Sci. USA, v. 96, p.7088-7092, 1999.

81. SMITH P. The effect of hypophysectomy upon the involution of the thymus in the rat. Anat Rec, v.47, p.119-143, 1930.

82. SPAGNOLI A, ROSENFELD RG. Insulin like growth factors binding proteins. Current Opinion in Endocrinology and Diabetes, v.4, p.1-9, 1997.

83. STUART CA, MEEHAN RT, NEALE LS, CINTRON NM, FURLANETTO RW. Insulin-like growth factor-I binds selectively to human peripheral blood monocytes and B-lymphocytes. J Clin Endocrinol Metab, v.72, p.1117-22, 1991.

84. TAMBORLANE W, HINTZ R, BERGMAN M, GENEL M, FELIG P, SHERWIN R. Insulin-infusion-pump treatment of diabetes: influence of improved metabolic control on plasma somatomedin levels. N Engl J Med, v. 305, p.303$307,1981$.

85. TATTERSALL RB, PYKE DA. Diabetes in identical twins. Lancet, v.ii, p.1120$1125,1972$.

86. THAI AC, EISENBARTH GS. Natural history of IDDM. Diabetes Reviews, v.1, p.1-14, 1993.

87. TORN C, LANDIN-OLSSON M, LERNMARK A, PALMER JP, ARNQVIST HJ, BLOHME G, LITHNER F, LITTORIN B, NYSTROM L, SCHERSTEN B, SUNDKVIST G, WIBELL L, OSTMAN J. Prognostic factors for the course of beta cell function in autoimmune diabetes. J Clin Endocrinol Metab, v. 85, p.46194623, 2000. 
88. TORN C, LANDIN-OLSSON M, LERNMARK A, SCHERSTEN B, ÖSTMAN J, ARNQVIST HJ, BJÖRK E, BLOHME G, BOLINDER J, ERIKSSON J, LITTORIN B, NYSTRÖM L, SUNDKVIST G. Combinations of beta cell specific autoantibodies at diagnosis of diabetes in young adults reflects different courses of beta cell damage. Autoimmunity, v.33, p.115-120, 2001.

89. TUOMILEHTO J, ZIMMET P et al. Antibodies to glutamic acid decarboxylase as predictors of insulin-dependent diabetes mellitus before clinical onset. Lancet, v.343, p.1383-1385, 1994.

90. UNDERWOOD LE, VAN WYK JJ. Normal and aberrant growth. In: Wilson JD; FOSTER DW. Williams Textbook of endocrinology. 8 ed. Philadelphia, W.B.Saunders, 1992. p. 1079-1138.

91. VALENTINIS B, BASERGA, R. IGF-I receptor signalling in transformation and differentiation. Molecular Pathology, v 54(3), p.133-137, 2001.

92. VERGE F, GIANANI R, KAWASI E, PIETROPAOLO M, JACKSON A, CHASE P, EISENBARTH S. Prediction of Type 1 Diabetes in First-Degree Relatives Using a Combination of Insulin,GAD and ICA512bdc/IA-2 Autoantibodies. Diabetes, v.46, p.926-933, 1996.

93. VIRTANEN SM, JAAKOLA L, RASANEN L, YLONEN K, ARO A, LOUNAMAA R et al. Nitrate and nitrite intake and the risk for type 1 diabetes in Finnish children. Diabetic Med, v.11, p. 656-662, 1994.

94. YOON JM. Viruses as triggering agents of insulin-dependent diabetes mellitus. In: Leslie, RDG. The causes of Diabetes. John Wiley \& Sons, London, p. 83-103, 1993 